\title{
Petrology of the Skien basaltic rocks, southwestern Oslo Region, Norway
}

\author{
TOM VICTOR SEGALSTAD
}

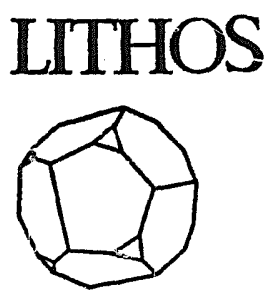

\begin{abstract}
Segalstad, T. V. 19:9: Petrology of the Skien basaltic rocks, southwestern Oslo Region, Norway. Lithos 12. 22 -239. Oslo. ISSN 0024-1937.

The pile of Permian continental basaltic rocks near Skien has a minimum thickness of i $509 \mathrm{~m}$, dipping 40: towards NE, coasisting of several thin lava flows. Most flows are porphyric, though both tuff's and aphyric flows occur to a lesser extent. Amygditles are abundant and a characteristic feature. The flows in the lower $2 / 3$ of the basalt pile are mainly classified as melanite-anikaramite; some in the middle part as melanite-nephelinite; and the upper $1 / 3$ of the flows as basanite. The basaitic rocks evolved from an assumed olivine-nephelinitic magma at great depths principally by clinopyroxene crystal fractionation accompanied by later olivine and maybe relilite reactions at moderate pressure in minor shallower magma chambers.
\end{abstract}

T. V. Segalstad, Institult for geologi, Universitetet i Oslo, P.O. Box 1047 Blindern, Oslo 3, Norway. Present cddress: Department of Geosciences, The Pennsylvania State University, 204 Deike Building, University Park, PA 16802, U.S.A.

The towns of Skien and Porsgrunn are situated in the NW-SE striking Gjerpen valley some $105 \mathrm{~km}$ SW of Osilo (Fig. 1). Basaltic rocks form the northeastern ridge of this valley. A northern body of basalts some $12 \mathrm{~km}$ NNW of Skien has a surface area of approximately $5 \mathrm{~km}^{2}$, while the main body of basalts $E$ of Skien covers some 45 $\mathbf{k m}^{2}$.

Early descriptions of basalts in the Oslo Region include Keilhau (1826), who called the rocks 'schwarze Porphyre (oder Basaltmassen) mit Augit-Krystallen', while Kjerulf (1855) called them 'Augit-Porhyr'. Breigger (1884) introduced the name 'Essexitmelaphyr' as a synonym for the former narnes. The basalts of different stratigraphic positions in the Oslo Region were given designations such as $E_{1}, E_{2}$, and $E_{3}$. Brøgger's 'essexites' were later called basalts by Barth (1945), and Oftedahl (19.52) replaced the ' $E$ '-symbols with ' $B$ '-symbols.

A profile through the geology of the Skien district was given by Dahll (1857). Brøgger (1884) mapped the faults, especially in the Largesundsfjorden area $S$ of the Skien District. Kiær (1906) described the geology of the CambroSilurian sedimentary rocks, while Brøgger (1933a) discussed the volcanic rocks in this district. Oftedahl (1952) placed the Skien basalts among the $B_{1}$ Oslo basalts; Weigand (1975) has presented five chemical analyses of the Skien basalts. Segalstad (1975) showed that the upper part of the block of basalts is cut by two cauldrons; the Vealøs and Skrehelle cauldrons.

The Skien basalts rest on Permian sedimentary rocks, which are poorly described except for the plant fossils (mainly Cordaites) reported by Høeg (1936). The sedimentary strata are continuous and not disturbed by early faults or joints as at Ringerike (B. Larsen, pers. comm.). In accordance with Brøgger (1933a) the basaltic sills in the upper sedimentary strata reported by Dahll (1857), appear to be discordant dikes.

The Permian sedimentary rocks consist mostly of red-coloured (some grey-coloured) sandstones and shales. The rocks are multicyclic composed dominantly of fine-grained clastic quartz and occasional small pyroslastic fragments of pyroxene, which are thought to be of tephraic origin from within a short distance. The red rock colour is due to the hematite-rich matrix. The upper $30 \mathrm{~m}$ of the Permian sediments were erroneotsly called tuffs by Dahll (1857). He descibed the dense hematite-rich rocks as 'tuffartige Straten'. The Permian sediments are terminated by a 1-2 m thick mionomict conglomerate (also described by Dahll 1857) with $1-2 \mathrm{~cm}$ well-rounded quartz pebbles, medium sorted and scattered throughout the matrix. Near the plutons the sandstone appears as metamorphic quartzite as in the north near the nordmarkite (syenite). In the Skien district the 

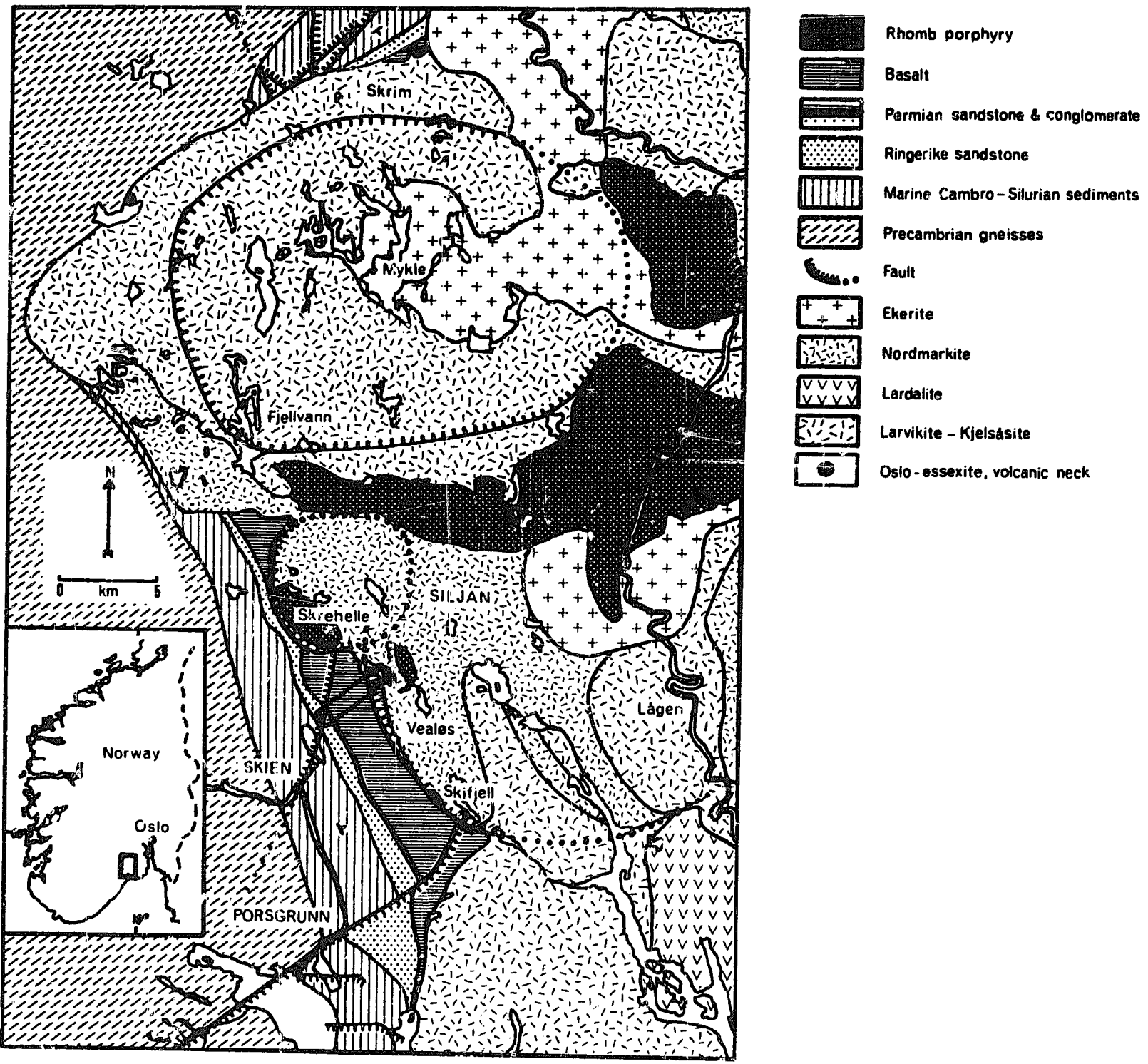

Fig. I. Geological map of the Skien district (after Segaistad 1975). The situation of the profile through the basaltic rocks (Figs. 2, 4) is shown beiween Skien and Siljan.

Permian sedimentary rocks and conglomerate sequence are estimated to be between 110 and $125 \mathrm{~m}$ thick. This thickness is greater than that of the similar well-known sequences near Oslo: 40 $\mathrm{m}$ thickness at Asker (Størmer 1966) and 23-35 m at Kolsås (Dons \& Györy 1967).

The basalts occur concordantly above the Permian sedimentary rocks, with nearly constant strike $150^{\circ}$ and dip $40^{8}$ towards NE. There are minimal thermal metamorphic effects on the underlyng sedimentary rocks. Tuffs are of local and restricted distribution and occur mostly in the south.

Due to the very uniform appearance of the Skien basalts, it was decided to carry out a detailed investigation of a profile through the basalts. This profile shouid ideally show fresh basalts unaffected by plutonic contact metamorphism or tectonism. It should also give an idea of the true thickness of the pile of basalts.

A profile with nearly continuous fresh road cuttings through the whole pile of basalts vas found $\mathrm{E}$ of Skien along the highv/ay from Skien to Siljan (Fig. 1). It is $2.5 \mathrm{~km}$ long and runs in a SW-NE direction from Åmot $(3.7 \mathrm{~km} \mathrm{NE}$ of Skien cathedral) to Heivann (Fig. 2).

As the profile contains mainly thin flows (Fig. 3) there are reasons to assume that the lava originated from shields or fissure. The profile is 


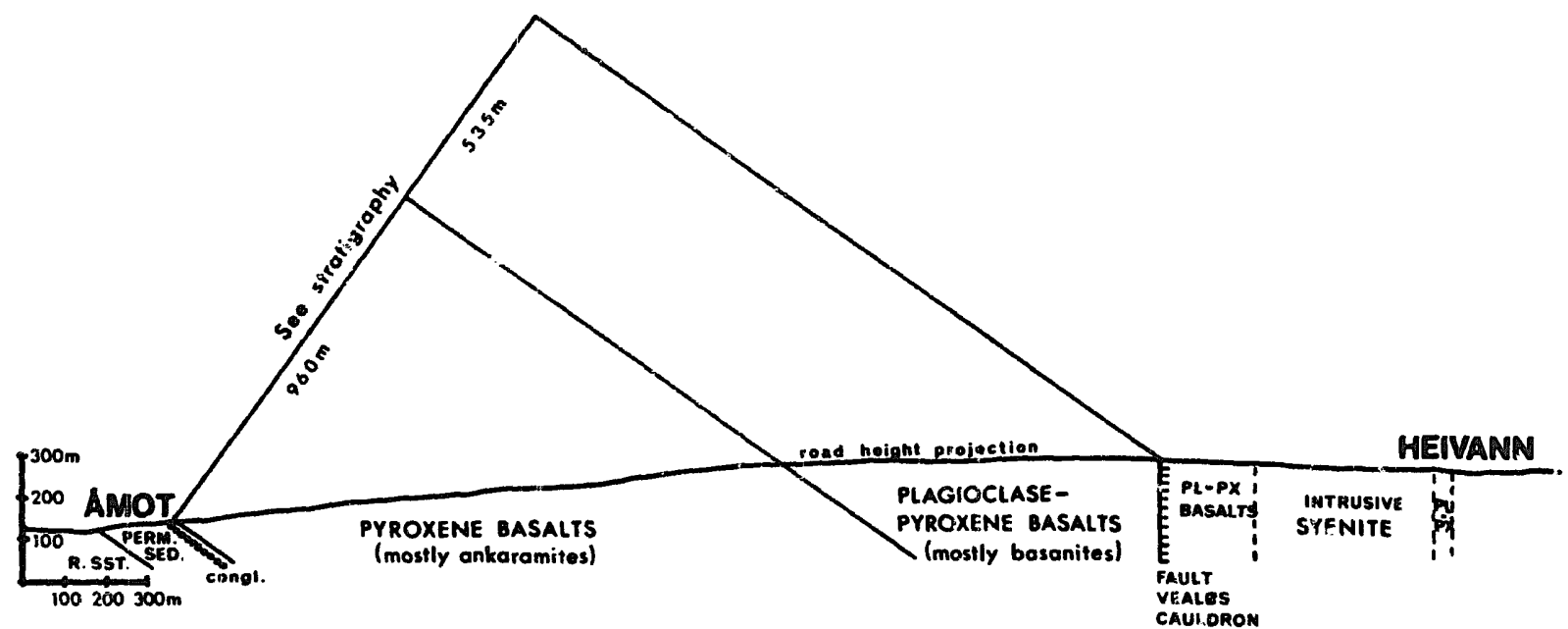

Fig. 2. Vertical projection of the road profile between Åmot and Heivann. R.SST. = Ringerike sandsłone. For stratigraphy see Fig. 4.

intended to give an impression of the magmatic conditions during the initiation of the rifting and volcanic episode in this part of the Oslo Region.

Dip is constant at $40^{3}$ up to the border of the Vealøs cauldron, giving $1495 \mathrm{~m}$ as the total apparent thickness of the basalts outside the Vealøs cauldron. This must be considered a minimum thickness of the Skien basalts, since huge xenoliths composed of basalts are found in the nordmarkite (syenite) inside the Vealøs cauldron. These xenoliths may have sunk in the syenite magma from a higher position in the lava flow sequence than is exposed today. Brøgger (1911, 1933a) believed the thickness of the Skien basalts to be $100 \mathrm{~m}$ (1911) or $>170 \mathrm{~m}$ (1933), and suggested that the apparently huge thickness of the basalts was due to tectonic repetition. However, neither Oftedahl (1952) nor the present writer have found indications of faults parallel to the strike, and the apparent thickness seems to be real. Oftedahl (1952) indicated a basalt thickness of $>200 \mathrm{~m}$, but recognized the possibility of the thickness being as much as $500 \mathrm{~m}$ or more. Ramberg (1976) contests Oftedahl's estimates of the basalt thickness, and states that the observed gravity anomaly applies to a slab of basaltic rocks with apparent stratigraphic thickness of about 2 $\mathrm{km}$, extending down to at least $2.5 \mathrm{~km}$ depth.

\section{Petrography}

The Skien basaltic rocks may be divided petrographically into three groups - porphyric basalts, aphyric basalts, and tuffs containing

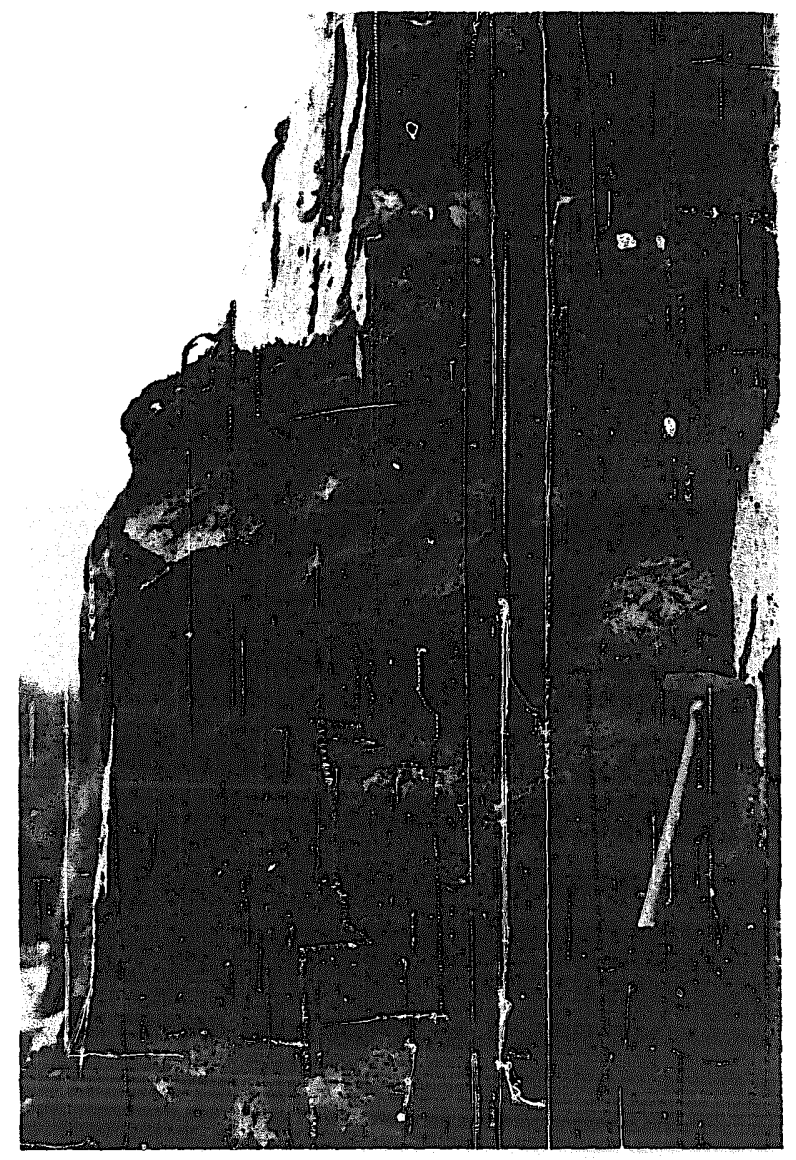

Fig. 3. Thin lava flows of melanite-nephelinite (sample S36). Tilted picture to show stratigraphy; the dip is false. Length of hammer $40 \mathrm{~cm}$. 
xenocrysts or xenoliths. Though most of the Skien basalts lack calcic plagioclase and therefore do not qualify to be called true basalts according to Streckeisen (1967), they are nevertheless throughout this paper called basaits for convenience, synonymousily with 'basaltic rocks'.

Amygdules are abundant and a characteristic feature of the Skien basalts. They are most often filled with calcite, but epidote, chlorite, zeolites, and albite also occur. The lava pile is composed of numerous small lava flows, usually $1-5 \mathrm{~m}$ thick, though both thinner $(20 \mathrm{~cm})$ and thicker (enp to $15 \mathrm{~m}$ ) flows occur. Pyroclastic rocks (tuffs and agglomerates) are seldom observed. The lower flows are dominated by pyroxene phenocrysts, while plagioclase also occurs as phenocrysts in the upper flows. No ultramafic nodules have ever been found in the Skien basalts despite an intensive search.

\section{Porphyric basalts}

Abundant euhedral clinopyroxene phenocrysts (3-10 mm across) are short, prisrnatic, and often found in groups or clusters. They are twinned and/or zoned, often in complex forms showing hour-glass structure. First and second generation pyroxenes have no pleochroism and may be corroded, third generation pyroxenes usually show a pale violet pleechroism due to their higher Ti contents (see below).

Inaltered olivine occurs in the lowest flows as euhedral phenocrysts (5-10 mm across) often with a serpentine-magnetite-clinopyroxene reaction rim (corona). Cracks are often filled with brown iddingsite. In some flows all olivine is altered to serpentine and magnetite or to green bowlingite and magnetite. Inclusions in olivine are rare, but are usually $\mathrm{Cr}$-rich magnetite.

Plagioclase phenocryst: occur in the upper flows as 10-15 mm elongated clusters or laths. They may be saussuritized and sericitized, and often show undulating extinction. Kaersutite occurs as elongated subhedral to euhedral phenocrysts (0.5$1.5 \mathrm{~mm}$ long).

The groundmass consists of apatite, melanite, magnetite, calcite, and occasionally sphene, nepheline, chalcopyrite. Apaxite may appear as euhedral laths or basal sections as microcrysts. Melilite may be present in the groundmass as 1-3 $\mu \mathrm{m}$ long grains (nicroprobe identification).

Secondary minerals are chlorite, eridote, serpentine, bowlingite. The texture is intergranular to intersertal.

\section{Aphyric basalts}

Euhedral clinopyroxene (usually $0.2-0.4 \mathrm{~mm}$ across, occasionally as phenocrysts $5 \mathrm{~mm}$ across) are short, prismatic, and often found in groups or clusters. They are less zoned than the pheriocrysts in the porphyric basalts, and are generally of the corresponding second generation with no pleochroism.

Plagioclase occurs as $\mathbf{0} 0.3-0.4 \mathrm{~mm}$ long) thin elongated albite-twinned laths, often with undulating extinction. Magnetite occasionally occurs in euficdral ( $0.5 \mathrm{~mm}$ across) crystals.
Secondary minerals are chlorite, serpentine, epidote, and bowlingite. The texture is intergranular to intersertal.

\section{Tuffs}

The tuffs can be subdivided into two types. Lapilli tuff occurs in the upper part of the profile (sample S63) with xenoliths (3-5 $\mathrm{cm}$ size) composed of porphyric basalt with pyroxene and plagioclase phenocrysts in a porphyric matrix of the same composition. Crystal tuff occurs in the lower part of the profile (sample S20, sample S27).

The pyroxenes are anhedral (3-5 mm across) and typically xenocrysts; they may be twinned and have strong violet pleochroism. Euhedral, now corroded, phenocrysts like those described from porphyric basalts also occur. The groundmass consists of brown-to-black basaltic glass (pumice), magnetite, calcite, and occasionally minor vesicles containing sphene. Secondary minerals are chlorite, serpentine, epidote, and bowlingite. The texture is intersertal and pumiceous.

\section{Alteration and metamorphism}

All samples have been subjected to some degree of deuteric alteration. Hydrothermal alseration has taken piace in the vicinity of larger joints. Thermal metamorphism from the nordinarkite intrusion and associated fluids have played some role in changing the original mineralogy of the basalts, especially in the upper part of the profile. Plagioclase is changed to sericite and epidote, pyroxene has been recrystallized or changed to chlorite and amphibole, olivine to serpentine or bowlingite. A few small crystals of idocrase, grossular, and recrystallized calcite have been observed in the huge contact metamorphic basalt xenoliths inside the Veal $\phi s$ cauldron, indicating hornfels-class X (Goldschmidt 1911) in Eskola's (1920-21) pyroxene-hornfels facies (K-feldspar-cordieritehornfels facies of Winkler (1967)).

\section{Classification}

Oftedahl $(1952,1957)$ classified the Oslo basalts as

1. Augite basalt (pyroxene basalt)

2. Plagioclase basalt (plagioclase basalt)

3. Non-porphyric basalt (aphyric basalt)

4. Augite-plagioclase basalt (plagioclasepyroxene basalt)

The classification was also adopted by Weigand (1975); his notation is shown in parentheses above. The distribution of basalt types is presented in Table 1 and Fig. 4.

The presence of clinopyroxene as the only pyroxene indicates alkali basalt affinities. Some of the plagioclase-free lava flows contain abundant pyroxene and olivine (only the lowermost lava flows have fresh olivine, others have distinct pseudomorphs or relicts of olivine) with pyroxene in excess of olivine. They would be called ankaramites. The abundance of melanite 
Table I. Distribution of basalt types in the profile Åmot-Heivann, Skien.*

\begin{tabular}{|c|c|c|}
\hline & $\begin{array}{l}\text { Apparent } \\
\text { thickness } \\
\text { (m) }\end{array}$ & $\begin{array}{l}\text { Abundance } \\
\text { (96) }\end{array}$ \\
\hline Aphyric basalts - & 71 & 4.3 \\
\hline \multicolumn{3}{|l|}{ Porphyric basalts: } \\
\hline Plagioclase basalts & 60 & 3.7 \\
\hline Plagioclase-pyroxene basalts & 607 & 36.9 \\
\hline \multicolumn{3}{|l|}{ Pyroxene basalts } \\
\hline $\left.\begin{array}{l}\text { (with amygdules } 725 \mathrm{~m}, 44.1 \% \text { ) } \\
\text { (without amygdules } 109 \mathrm{~m}, 6.6 \% \text { ) }\end{array}\right\}$ & 834 & 50.7 \\
\hline Pyroclastics & 4 & 0.2 \\
\hline Hiclden & 65 & 4.0 \\
\hline Sum & 1641 & 99.8 \\
\hline Total apparent thickness & 1645 & 100.0 \\
\hline
\end{tabular}

* 75\% of the basalts contain amygdules. Sediment layers or erosion horizons between the lava flows are most often lucking and may be only $1-2 \mathrm{~cm}$ thick if observed. Long eruption br:aks are therefore unlikely.

Fig. 4. Stratigraphy of the Skien basaltic rocks. Dikes (diabaiseand syenite dikes) are very scarce in this profile. They are often less than $1 \mathrm{~m}$ thick, striking NW-SE or NE-SW with vertical dip. (Top of the sequence in the left hand column.)
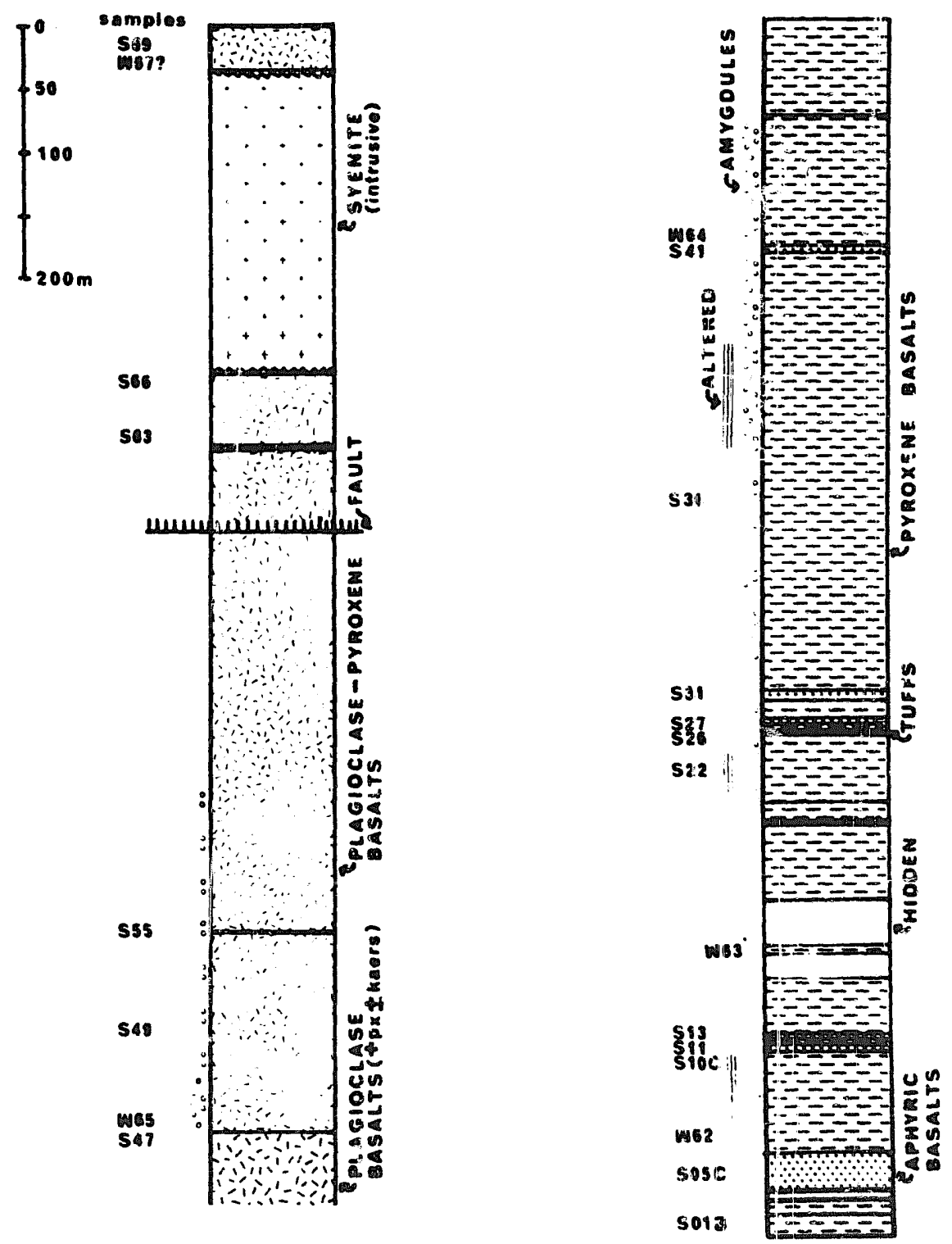
in groundmass justifies the name melaniteankaramite for the grey-coloured varieties.

The plagioclase-bearing flows and flows with abundant pyroxene are called basanites if modal nepheline is present, and basanitiodes where it is absent. Staining (Shand 1939; Mörtel 1971) showed that nepheline is present in the groundmass. Melanite-nephelinite thus occurs in the middle part of the basalt pile.

\section{Mineralogy}

\section{Analytical procedures}

Minerals were analysed with an ARL-EMX microprobe at the Central Institute of Industrial Research, Oslo, using series of natural and synthetic standards. The raw data were corrected for dead-time and background. Corrections for mass absorption and fluorescence were made by a procedure described by Bence \& Albee (1968) using correction factors from Albee \& Ray (1970). Each analysis represents the mean of 3-4 analysed points.

Contents of ferric iron have been calculated from charge balance according to Neumann (1976).

\section{Pyroxene}

The only pyroxene phase is a Ca-rich clinopyroxene. Typical pyroxene compositions from the Skien basaits are shown in Table 2. Chemical characteristics of the pyroxenes are listed in Table 3.

The pyroxene compositions are shown in a part of the Ca-Mg-Fe diagram in Fig. 5. The nomenclature of the clinopyroxenes is adopted from Polder vaart \& Hess (1951). It is seen from Fig. 5 that the pyroxene cores are diopsidic, while the intermediate zones and rims are salitic.

Table 2. Compositions of sume typical pyroxenes from the Skien basalts.

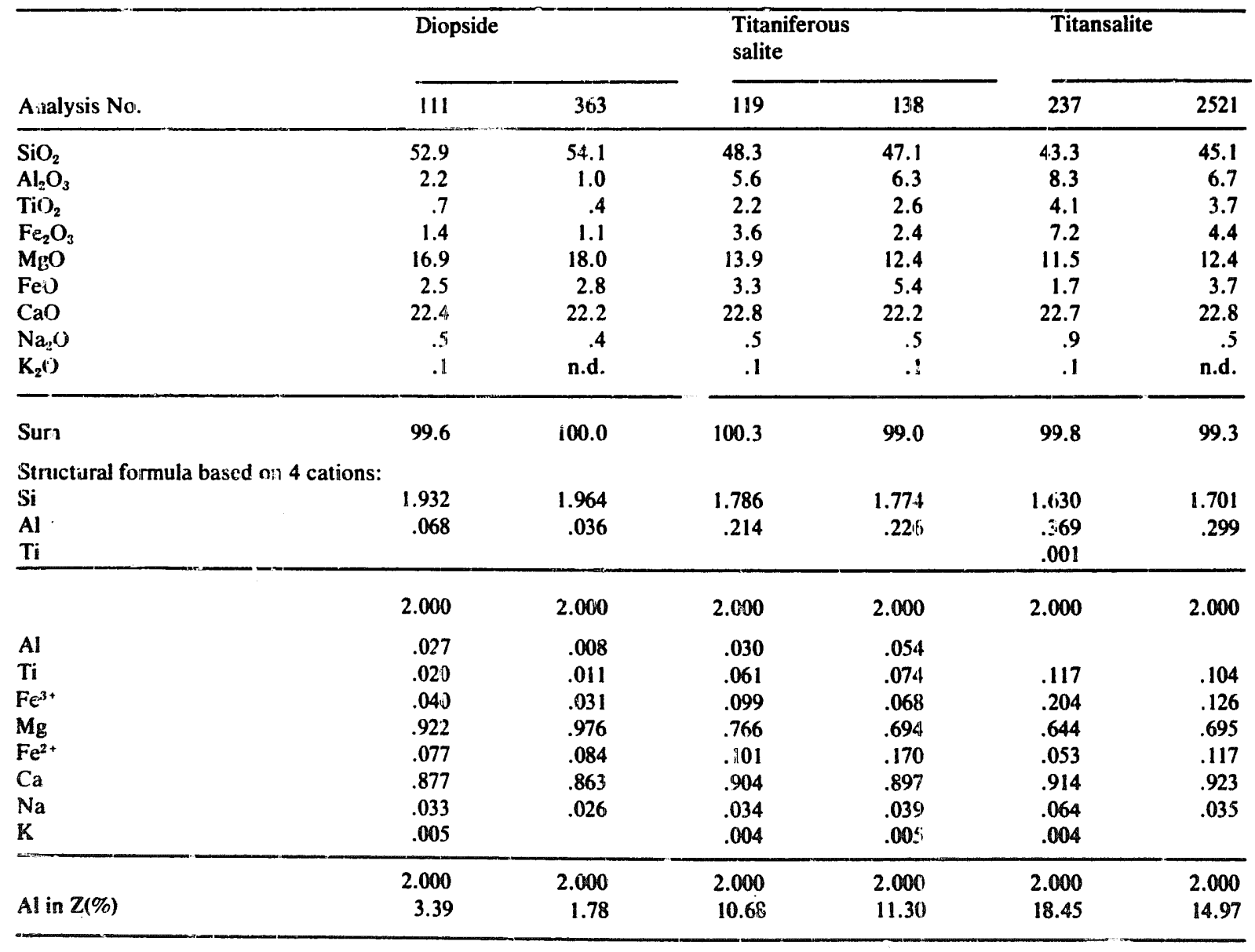

n.d. $=$ not detected. 
Table 3. Characteristic chemical features of pyroxenes int the Skien basaltic rocks.

\begin{tabular}{|c|c|c|c|}
\hline & Diopside & $\begin{array}{l}\text { Titaniferous } \\
\text { salite }\end{array}$ & Titansalite \\
\hline & $\begin{array}{l}\text { 1st generation } \\
\text { Often C }\end{array}$ & $\begin{array}{l}\text { 2nd generation } \\
\text { Often I }\end{array}$ & $\begin{array}{l}\text { 3rd generation } \\
\text { Often } \mathbf{R} \\
\end{array}$ \\
\hline $\mathbf{T i}$ & $\begin{array}{l}\text { Low } \\
\mathrm{TiO}_{2}<1.7\end{array}$ & $\begin{array}{l}\text { Intermediate } \\
1.7<\mathrm{TiO}_{2}<3.0\end{array}$ & $\begin{array}{l}\text { High } \\
\mathrm{TiO}_{2}>3.0\end{array}$ \\
\hline $\mathbf{M g}$ & $\begin{array}{l}\text { High } \\
\text { MgO > } 14.5\end{array}$ & $\begin{array}{l}\text { Intermediate } \\
13.0<\mathrm{MgO}<14.5\end{array}$ & $\begin{array}{l}\text { Low } \\
\mathrm{MgO}<13.0\end{array}$ \\
\hline Al & $\begin{array}{l}\text { Low } \\
\mathrm{Al}_{2} \mathrm{O}_{3}<4.0\end{array}$ & $\begin{array}{l}\text { Intermediate } \\
4.0<\mathrm{Al}_{2} \mathrm{O}_{3}<7.0\end{array}$ & $\begin{array}{l}\mathrm{High} \\
\mathrm{Al}_{2} \mathrm{O}_{3}>6.5\end{array}$ \\
\hline $\mathrm{Al}$ in $\mathrm{Z}$ & $\begin{array}{l}\text { Low } \\
\mathrm{Al}_{\mathrm{z}}<7\end{array}$ & $\begin{array}{l}\text { Incermediate } \\
7<\mathrm{Al}_{\mathrm{z}}<14\end{array}$ & $\begin{array}{l}\text { High } \\
\mathrm{Al}_{\mathrm{Z}}>14\end{array}$ \\
\hline
\end{tabular}

$C=$ core, $I=$ intermediate, $R=$ rim. Values in $\mathrm{Vt}_{0} \%$ metal oxide $\left(\mathrm{TiO}_{2}, \mathrm{MgO}, \mathrm{Al}_{2} \mathrm{O}_{3}\right)$ or \% abundance $(\mathrm{Al}$ in $\mathrm{Z})$. Limits are approximate. $\mathrm{Cr}$ and $\mathrm{Mn}$ are analysed in few pyroxenes; $\mathrm{Cr}$ seems to follow a trend from high $\mathrm{Cr}(0.4 \%)$ in diopside towards low $\mathrm{Cr}(0.1 \%)$ in salite.

Huckenholz (1965) and Deer et al. (1966) choose a lower limit of $3 \% \mathrm{TiO}_{2}$ for titanaugites or titansalites, and call those with 2 to $3 \% \mathrm{TiO}_{2}$ titaniferous augites or titaniferous salites. These limits compare well with the observed $\mathrm{TiO}_{2}$ limits between the Skien pyroxenes, which in general may be said to have diopsidic cores, titaniferous salitic intermediate zones, and titansalitic rims (Table 3).

Cata-norms calculated often show hypersthene and olivine but no nepheline in norins for the pyroxene cores, while the rims have norms with nepheline, negative values for quartz, and lack hypersthene and olivine. This presumably reflects the degree of undersaturation of the host magma producing the respective pyroxenes (see below).

The $\mathrm{Al}_{\mathrm{z}}$ and $\mathrm{Ti}$ contents of the salites tend to vary sympathetically. Yagi \& Onuma (1967) have suggested that these ions are mainly pre- sent as the hypothetical ticanpyroxene molecule Cat $: A_{2} \mathrm{O}_{6}$ whose maximum sollubility in diepsicis at atmospheric pressure is about $11 \%$, corresponding to $4 \% \mathrm{TiO}_{2}$. At high pressures (10-25 kbar) the solubility of $\mathrm{CaTiAl}_{2} \mathrm{O}_{6}$ in diopside decreases markedly, suggesting that most titanfugites are relatively low-pres Any $\mathrm{Al}$ in octahedral co-ordination is probably present mainly as Ca-Tschermak's molecule $\mathrm{CaAl}_{2} \mathrm{SiO}_{6}$. This substitution is favoured by high pressures according to Clark et al. (1962).

With the reservation that there has been no major change in magna composition during the time of pyroxene crystallization, the Skien basalts' pyroxene cores must have formed at higher pressures than the other pyroxene zones. This is consistent with the often observed resorption of the pyroxene cores.

The grass-green xenocryst salite pyroxenes in the crystal tuff sample S20, however, show
Fig. 5. Some typica! clinopyroxene analyses from the Skien basaltic rocks plo'ted in a part of the DI-HD-EN-FS field (shaded area of the key figure to the lower rigltt). Arrow's point from pyroxene core to rim. Nomenclature is adopted from Poldervaart \& Hess (1951). DI = $\mathrm{CaMgSi}_{2} \mathrm{O}_{6}$. $\mathrm{HD}=\mathrm{CaFeSi}_{2} \mathrm{O}_{6}$. $\mathrm{EN}=\mathrm{MgSiO}_{3} . \mathrm{FS}=\mathrm{FeSiO}_{3}$.

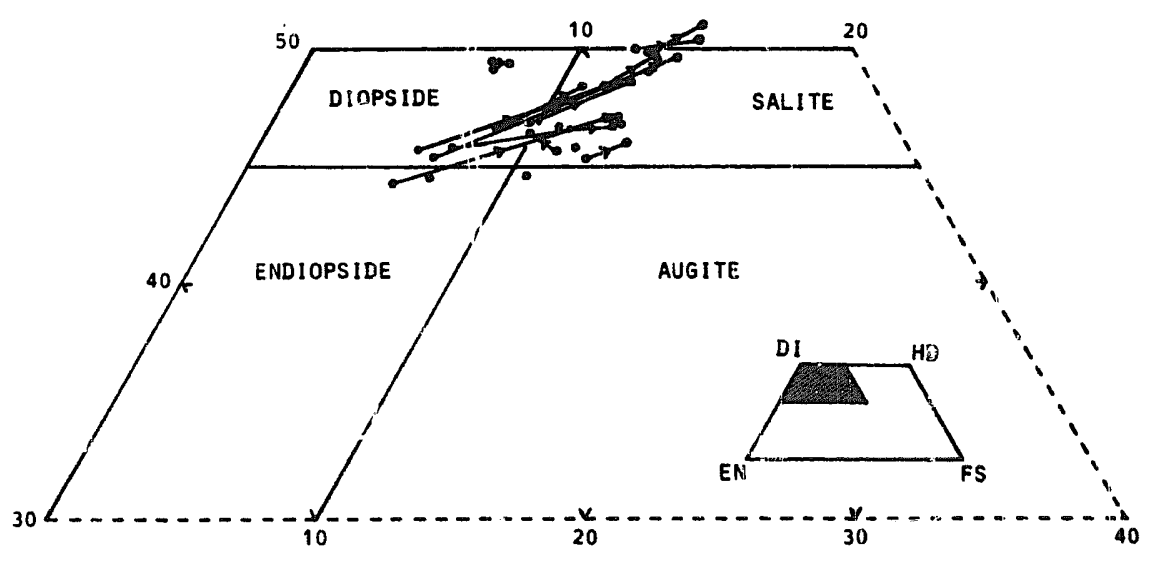


reverse zoning (Fig. 5). This feature has been described from several places, is for instance from east Greenland by Brooks \& Rucklidge (1973). They assume that these pyroxenes were subjected to an accidental change in $\mathrm{O}_{2}$-fugacity which might also have been the case during the extrusion history of the crystal tuff at Skien.

\section{Olivine}

A typical olivine analysis is shown in Table 4. Olivines in sample: S01 all give the composition $\mathrm{Fa}_{13}$. Zoning has not been observed in these olivines.

\section{Plagioclase}

The plagioclase lath compositions in the aphyric basalts are usually in the labradorite range (An 54). Plagioclase phenocrysts in the higher basalt flows, however, show compositions in the oligoclase range (An 20-30). Zoning has not been observed in the plagioclase.

\section{Kaersutite}

Kaersutite is a pargasitic amphibole in which $\mathrm{Ti}$ ranges from about 0.5 to 1 atom per formula unit. One typical kaersutite composition from sample $\mathrm{S} 47$ is presented in Table 4. The $\mathrm{TiO}_{2}$-contents of kaersutites from the Skien basalts is among the highest reported from rocks with similar chemistry.

Wilkinson (1974) states that the norms of many kaersutites are similar to those of olivine nephelinites, while Kesson \& Price (1972) assert that the composition of the nephelinitic 'minimum melt' is very close to that of kaersutite. Cyreen (1970a) has suggested that increasing degrees of partial melting in the low velocity zone produce basaltic liquids whose compositions pass gradually from nephelinite through basanite and alkali basalt to tholeiite. Kesson \& Price (1972) therefore conclude that kaersutite must be an accessory phase in the upper mantle.

Recent experimental work or the stability of kaersutite by Yagi et al. (1975) indicates that hornblendes can be stable up to 23-25 kbar at temperatures as low as $600-700^{\circ} \mathrm{C}$, i.e. hornblende can be stable not only in the lower crust, but also in the upper mantle. It is espe- cially noteworthy that kaersutite is associated in these experiments with Ti-poor clinopyroxene, garnet, and perovskite. The chemistry of this paragenesis is equivalent to the chemistry of the mineral paragenesis in the Skien basalts, as discussed below.

\section{Melanite}

The reddish coloured groundmass mineral with brownish or greyish shades is fairly abundant in some of the Skien basalts. Three samples of groundmass from S01, S36, and S41 were separated from the crushed rock specimens under a binocular microscope, and X-ray films made at the Geological Museum, Oslo, showed typical garnet (andradite) patterns. An average of seven grcundmass melanite analyses from samples S01, S36, and S41 is shown in Table 4. There was great spread in compositions due to the small size of the analysed grains.

Melanite is normally associated with rocks of the ijolite-melteigite series or their late-stage differentiation products. Bailey (1974) states that melanite and melilite are accessory minerals in nephelinite lavas, without giving any examples. He further states that porphyric melanite may be present in olivine-free nephelinite. Yoder (1973) ascertains that melanite is a common associate of melilite.

\section{Sphene}

Sphene occurs in small vesicles of assumed late-stage crystallization in tuffs. One typical analysis from sample $S 27$ is shown in Table 4.

\section{Magnetite}

Three chemically different types of magnetite occur in the Skien basaltic rocks. Titano-magnetite occurs as the normal groundmass ore. $\mathrm{Cr}$ rich magnetite is found in minor amounts as inclusions in olivine. Nearly pure magnetite is found in the reaction zone around olivine phenocrysts, between olivine and serpentine. The groundmass titano-magnetite is the common groundmass ore through almost the whole section of basalts, though ilmenite exsolution lamellae are seen in magnetite in the highest lava flows. 
Table 4. Compositions and structural formulas of typical olivine $\left(\mathrm{Fa}_{13}\right)$, kasisutite, sphene, and average of 7 melanites from the Skien basalts.

\begin{tabular}{|c|c|c|c|c|}
\hline $\begin{array}{l}\text { Mineral } \\
\text { Analysis No. }\end{array}$ & $\begin{array}{l}\text { Olivine } \\
012\end{array}$ & $\begin{array}{l}\text { Kaersutite } \\
472\end{array}$ & $\begin{array}{l}\text { Melanite } \\
\text { average }\end{array}$ & $\begin{array}{l}\text { Sphene } \\
272\end{array}$ \\
\hline $\begin{array}{l}\mathrm{SiO}_{2} \\
\mathrm{Al}_{2} \mathrm{O}_{3} \\
\mathrm{TiO}_{2} \\
\mathrm{Fe}_{2} \mathrm{O}_{3} * \\
\mathrm{MgO}^{*} \\
\mathrm{FeO}^{*} \\
\mathrm{MnO} \\
\mathrm{CaO} \\
\mathrm{Na}_{2} \mathrm{O} \\
\mathrm{K}_{2} \mathrm{O} \\
\mathrm{Cr}_{2} \mathrm{O}_{3} \\
\mathrm{H}_{2} \mathrm{O}\end{array}$ & $\begin{array}{r}40.7 \\
\text { n.d. } \\
\text { tr. } \\
46.5 \\
12.6 \\
.3 \\
.5 \\
\text { tr. } \\
\text { tr. } \\
\text { tr. }\end{array}$ & $\begin{array}{r}39.1 \\
11.9 \\
7.0 \\
13.3 \\
11.4 \\
.3 \\
11.5 \\
2.8 \\
1.0 \\
\text { tr. } \\
2.00\end{array}$ & $\begin{array}{r}36.98 \\
6.70 \\
6.32 \\
16.75 \\
3.15 \\
\\
\text { n.a. } \\
27.23 \\
.56 \\
.99 \\
\text { n.a. }\end{array}$ & $\begin{array}{r}31.6 \\
2.4 \\
31.7 \\
5.0 \\
1.3 \\
\\
\text { n.a. } \\
25.9 \\
.2 \\
.2 \\
\text { n.a. }\end{array}$ \\
\hline Sum & 103.6 & 100.3 & 98.68 & 98.3 \\
\hline $\begin{array}{l}\text { Oxygens } \\
\mathrm{Si} \\
\mathrm{Al} \\
\mathrm{Ti}\end{array}$ & $\begin{array}{c}4 \\
1.006\end{array}$ & $\begin{array}{c}23 \\
5.798 \\
2.096 \\
.116\end{array}$ & $\begin{array}{l}24 \\
5.946 \\
.054\end{array}$ & $\begin{array}{c}20 \\
4.106\end{array}$ \\
\hline & 1.006 & 8.000 & 6.000 & 4.106 \\
\hline $\begin{array}{l}\mathrm{Al} \\
\mathrm{Ti} \\
\mathrm{Fe}^{3+} \\
\mathrm{Mg} \\
\mathrm{Fe}^{2+} \\
\mathrm{Mn} \\
\mathrm{Ca} \\
\mathrm{Na} \\
\mathrm{K} \\
\mathrm{Cr} \\
\end{array}$ & $\begin{array}{r}1.710 \\
.260 \\
.067 \\
.0: 2 \\
\text { ir. } \\
\text { ir. } \\
\text { ir. }\end{array}$ & $\begin{array}{r}.669 \\
2.932 \\
1.407 \\
.031 \\
1.830 \\
.813 \\
.183 \\
.005\end{array}$ & $\begin{array}{r}1.216 \\
.764 \\
2.027 \\
.755\end{array}$ & $\begin{array}{r}.366 \\
3.096 \\
.487 \\
.256\end{array}$ \\
\hline $\mathrm{Cr}$ & 1.9499 & 7.870 & 9.830 & 7.894 \\
\hline
\end{tabular}

* As total Fe. n.a. = not analysed, n.d. $=$ not detected, $t r .=$ trace. The kaersutite composition was calculat 2 assuming $2.00 \% \mathrm{H}_{2} \mathrm{O}$.

\section{Whole rock geochemistry}

Whole rock major element analyses were executed by $\mathrm{X}$-ray fluorescence spectrometry $(\mathrm{Si}$, $\mathrm{Ti}, \mathrm{Al}, \mathrm{Fe}$ (total $\mathrm{Fe}$ as $\mathrm{Fe}_{\sharp} \mathrm{O}_{3}$ ), $\mathrm{Mn}, \mathrm{Mg}, \mathrm{Ca}, \mathrm{K}$, $P$ ), instrumental neutron activation analyses $(\mathrm{Na})$, and wet-chemical analyses ( $\mathrm{FeO})$.

Whole rock chemical analyses and cata-norms of volcanic rocks from the Skier district are listed in Table 5. Samples denoted with the prefix ' $W$ ' are from Weigand (1975). Mean, precision, range, and accuracy of the basalts analysed by the author are shown in Table 6.

The high $\mathrm{TiO}_{2}$ content is noteworthy and was confirmed in two samples by wet chemical analyses by $\mathrm{B}$. Brun: SOlB with $3.21 \% \mathrm{TiO}_{2}$, and $\mathrm{S} 31$ with $4.00 \% \mathrm{TiO}_{2}$. These analyses indi- cate that the values obtained by the $\mathrm{X}$-ray fluorescence spectrometer might even be a little too low.

The difference in sums from $100 \%$ is caused by the loss of volatiles $\left(\mathrm{H}_{2} \mathrm{O}+\mathrm{CO}_{2}\right.$ (mainly) and $\mathbf{F}+\mathrm{Cl}+\mathbf{S}$ ) duririg sample preparation. This is especially true of sample $\$ 47$, which contains abundant hydrous silicates (kaersutite and serpentine).

The norm calculations give abindant nepheline and olivine as a common feature of nearly ail samples. A strange feature, however, is that the norms of samples SOl and \$336 show negative quartz values. This is due to the extremely high $\mathrm{Ca}$ contents, which results in silica undersaturation. The 'excess' $\mathrm{Ca}$ is salculated into anorthite and wollastonite (as in \$36), in- 
Table 5. Whole rock chemical analyses and cata-norms of volcanic rocks from the Skien district.

\begin{tabular}{|c|c|c|c|c|c|c|c|c|c|c|c|c|}
\hline $\begin{array}{l}\text { Rock } \\
\text { Sample }\end{array}$ & $\begin{array}{l}\text { Am } \\
\text { SOIB }\end{array}$ & $\begin{array}{l}\text { Am } \\
\text { S05C }\end{array}$ & $\begin{array}{l}\text { Am } \\
\text { W62 }\end{array}$ & $\begin{array}{l}\text { Am } \\
\text { S10C }\end{array}$ & $\begin{array}{l}\text { Am } \\
\text { S11 }\end{array}$ & $\begin{array}{l}\text { Bn } \\
\text { S13 }\end{array}$ & $\begin{array}{l}\text { Am } \\
\text { W63 }\end{array}$ & $\begin{array}{l}\text { AtAm } \\
\text { S22 }\end{array}$ & $\begin{array}{l}\text { Am } \\
\text { S26 }\end{array}$ & $\begin{array}{l}\text { TuAm } \\
\text { S27 }\end{array}$ & $\begin{array}{l}\text { AtAm } \\
\text { S31 }\end{array}$ & $\begin{array}{l}\mathrm{Ne} \\
\text { S36B }\end{array}$ \\
\hline $\begin{array}{l}\mathrm{SiO}_{2} \\
\mathrm{CiO}_{2} \\
\mathrm{Al}_{2} \mathrm{O}_{3} \\
\mathrm{Fe}_{2} \mathrm{O}_{3} \\
\mathrm{FeO} \\
\mathrm{MnO} \\
\mathrm{MgO} \\
\mathrm{CaO} \\
\mathrm{Na}_{2} \mathrm{O} \\
\mathrm{K}_{2} \mathrm{O} \\
\mathrm{P}_{2} \mathrm{O}_{3}\end{array}$ & $\begin{array}{c}41.8 \\
3.09 \\
8.0 \\
7.3 \\
3.3 \\
.18 \\
11.5 \\
18.78 \\
1.45 \\
1.89 \\
.59\end{array}$ & $\begin{array}{c}42.8 \\
2.94 \\
10.6 \\
7.7 \\
5.0 \\
.20 \\
11.0 \\
13.36 \\
1.78 \\
2.55 \\
.35\end{array}$ & $\begin{array}{c}44.7 \\
2.88 \\
11.2 \\
7.0 \\
5.4 \\
.17 \\
8.27 \\
13.56 \\
1.55 \\
2.17\end{array}$ & $\begin{array}{c}43.0 \\
3.46 \\
12.5 \\
7.0 \\
6.6 \\
.21 \\
8.5 \\
12.63 \\
2.03 \\
2.28 \\
.35\end{array}$ & $\begin{array}{c}44.3 \\
3.24 \\
11.0 \\
6.3 \\
6.4 \\
.20 \\
10.8 \\
12.85 \\
1.94 \\
2.21 \\
.39\end{array}$ & $\begin{array}{c}45.0 \\
3.40 \\
15.2 \\
6.7 \\
7.6 \\
.24 \\
6.6 \\
7.91 \\
3.05 \\
3.53 \\
.60\end{array}$ & $\begin{array}{c}42.3 \\
3.95 \\
11.4 \\
5.5 \\
8.5 \\
.18 \\
7.79 \\
12.70 \\
2.93 \\
1.22\end{array}$ & $\begin{array}{c}44.7 \\
3.14 \\
13.7 \\
5.3 \\
6.2 \\
.18 \\
8.6 \\
10.04 \\
3.86 \\
1.44 \\
.53\end{array}$ & $\begin{array}{c}45.2 \\
3.04 \\
9.2 \\
6.4 \\
6.3 \\
.19 \\
11.5 \\
12.16 \\
2.79 \\
1.64 \\
.45\end{array}$ & $\begin{array}{c}46.0 \\
3.13 \\
11.0 \\
5.3 \\
7.3 \\
.19 \\
10.0 \\
10.42 \\
3.33 \\
1.75 \\
.50\end{array}$ & $\begin{array}{c}43.1 \\
3.89 \\
13.0 \\
6.7 \\
7.0 \\
.28 \\
6.7 \\
12.07 \\
4.40 \\
.78 \\
.61\end{array}$ & $\begin{array}{c}36.9 \\
3.32 \\
10.6 \\
8.4 \\
4.1 \\
.27 \\
7.7 \\
19.04 \\
3.38 \\
1.32 \\
1.81\end{array}$ \\
\hline $\begin{array}{l}\text { Sum } \\
\text { Rb } \\
\text { Sr } \\
\text { Th } \\
\text { U }\end{array}$ & 97.9 & 98.3 & $\begin{array}{c}96.90 \\
26 \\
1409 \\
5.9 \\
1.4\end{array}$ & 98.6 & 99.6 & 99.8 & $\begin{array}{l}6.8 \\
1.5\end{array}$ & 97.7 & 98.9 & 98.5 & 98.5 & 96.8 \\
\hline $\begin{array}{l}\text { Cata-nor } \\
\mathbf{Q}\end{array}$ & $\begin{array}{l}\text { ms: } \\
-1.96\end{array}$ & & & & & & & & & & & -2.92 \\
\hline $\begin{array}{l}\text { OR } \\
A \mathbb{B} \\
\mathbf{A N} \\
\mathbf{L C}\end{array}$ & 10.03 & $\begin{array}{r}11.27 \\
13.74 \\
3.33\end{array}$ & $\begin{array}{r}13.49 \\
8.52 \\
18.10\end{array}$ & $\begin{array}{r}13.90 \\
5.34 \\
18.85\end{array}$ & $\begin{array}{r}13.21 \\
5.26 \\
14.96\end{array}$ & $\begin{array}{l}21.18 \\
15.50 \\
17.64\end{array}$ & $\begin{array}{r}7.59 \\
7.47 \\
15.12\end{array}$ & $\begin{array}{r}8.67 \\
19.07 \\
16.13\end{array}$ & $\begin{array}{r}9.81 \\
12.06 \\
7.84\end{array}$ & $\begin{array}{l}10.46 \\
17.96 \\
10.02\end{array}$ & $\begin{array}{r}4.72 \\
15.90 \\
13.75\end{array}$ & 10.29 \\
\hline $\begin{array}{l}\mathrm{NE} \\
\mathrm{KP} \\
\mathrm{WO} \\
\mathrm{HY}\end{array}$ & $\begin{array}{l}8.04 \\
6.89\end{array}$ & 9.83 & 3.67 & 8.08 & 7.42 & 7.39 & 12.13 & 9.77 & 7.99 & 7.37 & 14.74 & $\begin{array}{r}18.99 \\
4.88 \\
7.74\end{array}$ \\
\hline $\begin{array}{l}\text { DI } \\
\text { OL }\end{array}$ & $\begin{array}{r}65.50 \\
.16\end{array}$ & $\begin{array}{r}41.47 \\
8.04\end{array}$ & $\begin{array}{r}42.15 \\
2.43\end{array}$ & $\begin{array}{r}34.75 \\
5.79\end{array}$ & $\begin{array}{r}37.56 \\
9.55\end{array}$ & $\begin{array}{l}14.59 \\
10.50\end{array}$ & $\begin{array}{r}40.97 \\
4.87\end{array}$ & $\begin{array}{l}24.9 i \\
10.21\end{array}$ & $\begin{array}{l}40.22 \\
10.07\end{array}$ & $\begin{array}{l}31.17 \\
11.95\end{array}$ & $\begin{array}{r}34.79 \\
2.08\end{array}$ & 45.24 \\
\hline $\begin{array}{l}\text { MT } \\
\text { HE }\end{array}$ & $\begin{array}{l}1.25 \\
4.40\end{array}$ & $\begin{array}{l}5.61 \\
1.76\end{array}$ & $\begin{array}{r}6.87 \\
.55\end{array}$ & 7.55 & 6.66 & 7.11 & 6.05 & 5.65 & 6.77 & 5.60 & 7.17 & $\begin{array}{l}2.70 \\
4.30\end{array}$ \\
\hline $\begin{array}{l}\text { IL } \\
\text { AP }\end{array}$ & $\begin{array}{l}4.43 \\
1.27\end{array}$ & $\begin{array}{r}4.20 \\
.75\end{array}$ & 4.22 & $\begin{array}{r}4.97 \\
.76\end{array}$ & $\begin{array}{r}4.57 \\
.82\end{array}$ & $\begin{array}{l}4.81 \\
1.27\end{array}$ & 5.79 & $\begin{array}{l}4.16 \\
1.63\end{array}$ & $\begin{array}{r}4.29 \\
.95\end{array}$ & $\begin{array}{l}4.41 \\
1.06\end{array}$ & $\begin{array}{l}5.55 \\
1.31\end{array}$ & $\begin{array}{l}4.83 \\
3.95\end{array}$ \\
\hline
\end{tabular}

volving more $\mathrm{SiO}_{2}$ than is present in the znalyses. The presence of melanite in the samples will produce a silica-deficient norm. Attention must at this point also be drawn to the pyrcoxene norm calculations in which the salitic pyrcoxenes display the same feature.

This feature also occurs in the East African undersaturated rocks, and in agreement with King (1965) the silica deficiency is accounted for largely by the following relationship among norrnative and modal minerals:

$3 \mathrm{CaSiO}_{3}$
wollastonite $\quad \begin{aligned} & \mathrm{Fe}_{2} \mathrm{O}_{3} \\ & \text { hematite } \\ & \text { (or in } \\ & \text { magnetite) }\end{aligned} \quad \begin{aligned} & \mathrm{Ca}_{3} \mathrm{Fe}_{2} \mathrm{Si}_{3} \mathrm{O}_{12} \\ & \text { melanite } \\ & \text { (andradite) }\end{aligned}$

Main elements as wt.\% oxides are plotted in the $\mathrm{SiO}_{2}-\mathrm{Na}_{2} \mathrm{O}+\mathrm{K}_{2} \mathrm{O}$ variation ('Harker') diagram together with a number of empirical dividing lines (Fig. 6). The 'Hawsii' line by Macdonald \& Katsura (1964) separates the alkaline (NEnormative) and subalkaline (HY-normative) rocks in Hawaii. The 'Japan' line by Kuno (1960) separates his high-alumina basalts $(\mathrm{NE}=\mathrm{O}, \mathrm{HY}$ $<10 \%$ ) from tholeiites (Q-normative) in Japan.

Weigand (1975) classified the Oslo basalts in accordance with this scheme, and showed that they are members of the alkali basalt association, though the aphyric basalts from $B_{1}$ in Barum have tholeiitic characteristics. The alkali basalts may be further subdivided with the 'Moheli' line of Strong (1972), separating basani- 


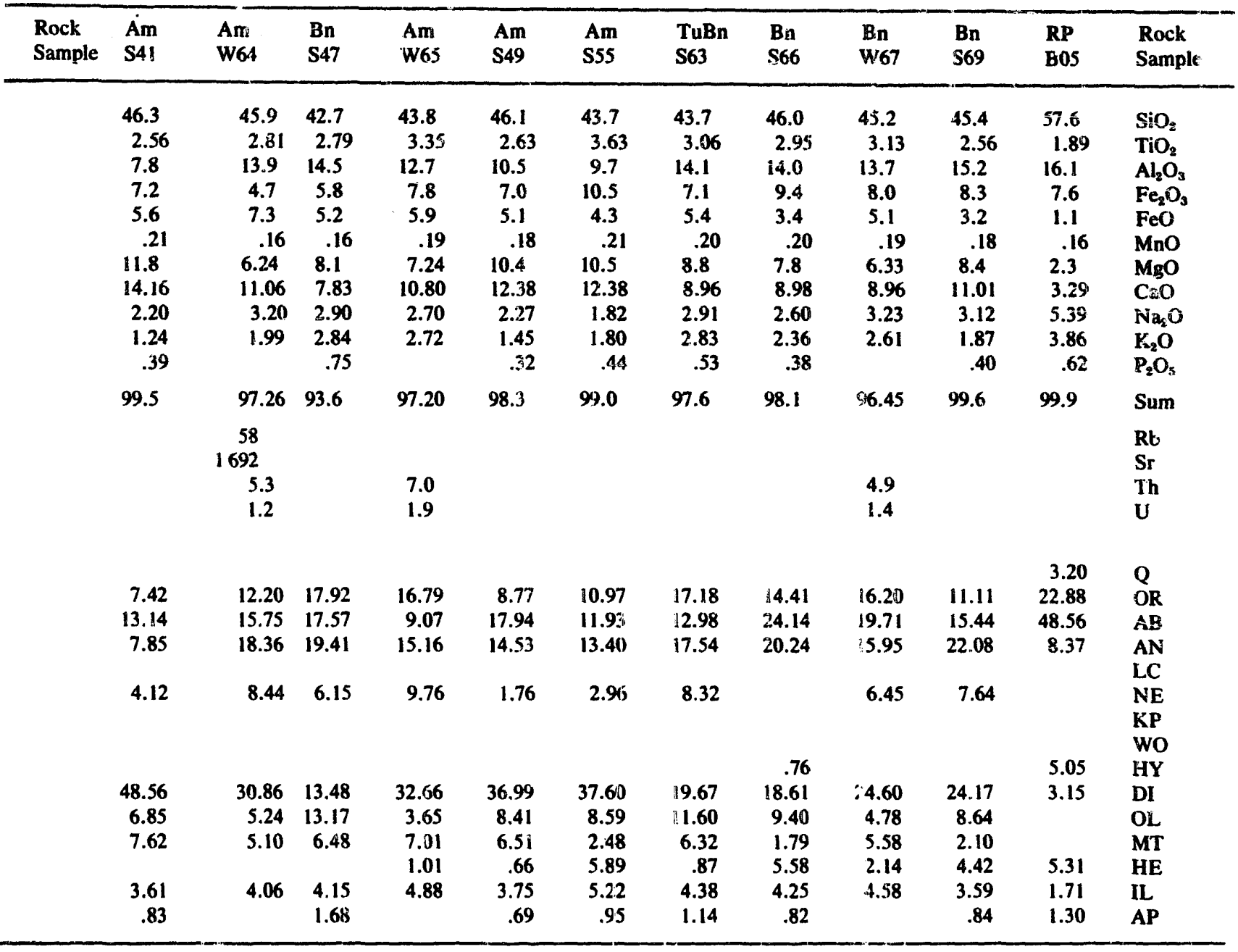

Samples with prefix ' $S$ ' are Skien basalts from the profile Amot-Fleivann, prefix ' $W$ ' are Skien basalts analysed by Weigand: (1975), from the same profile. Sainple B05 is a latite (RP) from trigonometric point $552 \mathrm{~m}$ above sea level at the peak Skrehelle $8 \mathrm{~km}$ NE of Skien. sill values are in wt.\%, except for $\mathrm{Rb}, \mathrm{Sr}, \mathrm{Th}, \mathrm{U}$ listed as ppm. Mean, precision, range, and accuracy of the basaltic rocks analysed by the author are shown in Table 6 . Am $=$ :ankaramite, $\mathrm{Bn}=$ basanite, $\mathrm{Ne}=$ nephelinite, $\mathrm{Tu}=$ tuff, $\mathrm{At}=$ altered.

tic rocks (NE > 5\%) and alkali basalts $\left(\mathrm{NE}_{1}<\right.$ $5 \%$ ) in the Western Indian Ocean. The 'Kenya' line of Saggerson \& Williams (1964) separates nephelinitic (modal nepheline-bearing; corresponding to approx. NE $>10 \%$ ) and basanitic rocks (nepheline occult or lacking, $5 \%<\mathrm{NE}<$ $10 \%$ ) in Eas.t Africa.

In the $\mathrm{SiO}_{2}-\mathrm{Na}_{2} \mathrm{O}+\mathrm{K}_{2} \mathrm{O}$ diagram with the dividing lines described above (Fig. 6), the samples of the Skien basalts plot in the alkali basalt field; a fev as alkali basalt, most in the basanite field, while: somie plot in the nephelinite field.

The ankaramites group around the basanite field at lov/er alkali values $(3-4.5 \%)$ than the basanites which cluster around the 'Kenya'-line between basanites and nephelinites at a higher alkali content (5-6.5\%). One nephelinite sample plots in an isolated position at low silica $(\sim 37 \%)$ and medium alkalis $(\sim 4.7 \%)$. Some altered samples assumed to be ankaramites plot near or inside the lowest part of the basanite field.

\section{Petrological evolution}

The experimental work of Green \& Ringwood (1967) demonstrated that magmas naight fractionate to yield different fractionation trends at different pressures (depths). Low pressure or shallow crustal fractionation $(<15 \mathrm{~km}$ depth) is dominated by olivine as the liquidus phase with clinopyroxene \pm plagioclase appearing at lower 
Table 6. The Skien basaltic rocks; mean, precision, range, and accuracy of the whole rock chemical analyses. (Analyses by Weigand (1975) are omitted.)

\begin{tabular}{lclll}
\hline Oxide & Mean & $\begin{array}{l}\text { Precision } \\
\pm \% \text { relative }\end{array}$ & Range & $\begin{array}{l}\text { Accuracy } \\
\pm \% \text { relative }\end{array}$ \\
\hline $\mathrm{SiO}_{2}$ & 43.92 & 0.35 & $36.9-46.3$ & 2.26 \\
$\mathrm{TiO}_{2}$ & 3.11 & 0.26 & $2.56-3.89$ & 4.05 \\
$\mathrm{Ai}_{2} \mathrm{O}_{3}$ & 11.80 & 0.69 & $7.8-15.2$ & 3.78 \\
$\mathrm{Fe}_{2} \mathrm{O}_{3}$ & 7.2 & & $4.7-10.5$ & \\
$\mathrm{FeO}$ & 5.4 & & $3.2-7.6$ & \\
$\mathrm{MnO}$ & 0.21 & 0.73 & $0.16-0.28$ & 6.51 \\
$\mathrm{MgO}$ & 9.34 & 1.53 & $6.6-11.8$ & 2.07 \\
$\mathrm{CaO}$ & 12.06 & 0.58 & $7.83-19.04$ & 0.97 \\
$\mathrm{Na}_{2} \mathrm{O}$ & 2.70 & $1.66 *$ & $1.45-4.40$ & 0.57 \\
$\mathrm{~K}_{2} \mathrm{O}$ & 1.99 & 0.21 & $0.78-3.53$ & 0.57 \\
$\mathrm{P}_{2} \mathrm{O}_{5}$ & 0.55 & 2.63 & $0.32-1.81$ & 7.83 \\
\hline $\mathrm{Sum}_{\mathrm{Total}}$ & 98.28 & & & \\
as $\mathrm{Fe}_{2} \mathrm{O}_{3}$ & 13.18 & 0.48 & $10.93-15.32$ & 0.90 \\
\hline
\end{tabular}

* Based on only 7 duplicates.

The precision of the analyses is given as standard error of the mean, determined using pooled estinate of variance for all samples determined in duplicate. The accuracy of the standard curve is an expression of the scatter of the standard points about it, called the relative standard deviation from the standard curve.

temperatures. Fractionation at about $15-35 \mathrm{~km}$ depth is ciominated at the early stage by olivine, but the olivine is joined by clinopyroxene as the second phase in the alkali basalt composition. Plagioclase only appears at temperatures very near the solidus. Fractionation at about 35-70 $\mathrm{km}$ depth is dominated by separation of aluminous orthopyroxene or orthopyroxene + subcalcic augite. This fractionation yields olivine-rich alkali basaltic magmas. Fractionation at atmos- pheric pressure gives increase in silica and moderate increase in alkalis; while fractionation at about $13-18 \mathrm{kbar}$ ( $40-60 \mathrm{~km}$ ) gives a silica-deficient melt strongly enriched in alkalis. The chemical variation as a function of the stratigraphy has been tested for the Skien basalts. The analyses of the bottom (B), middle (M), and the top (T) sequences of the basalts plot differently in an alkali-silica diagram shown in Fig. 7 . Samples S13 (C), S36 (D), S41 and 549

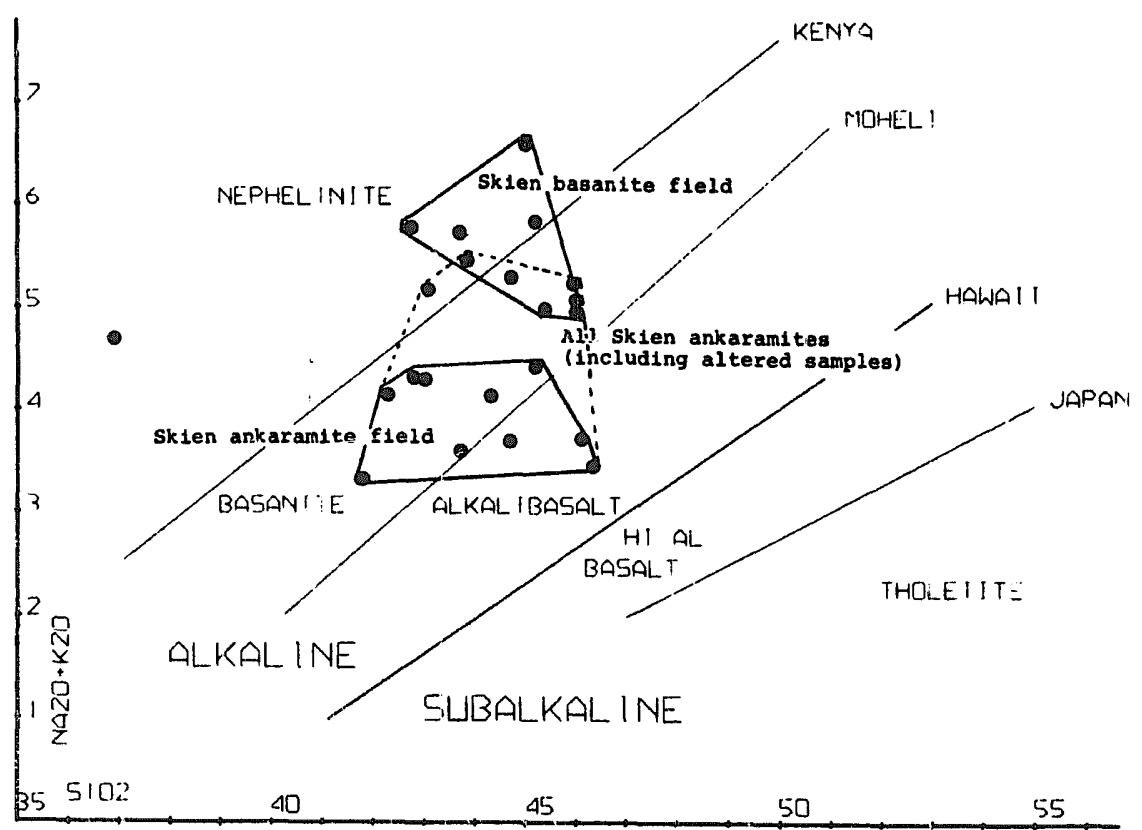

Fig. 6. $\mathrm{SiO}_{2}-\mathrm{Na}_{2} \mathrm{O}+\mathrm{K}_{2} \mathrm{O}$ variation diagram with plivis from the Stien basaltic rocks. 
Fig. 7. $\mathrm{SiO}_{2}-\mathrm{Na}_{2} \mathrm{O}+\mathrm{K}_{2} \mathrm{O}$ variation diagram with plots from the Skien basaltic rocks. Arrow shows the general trend of evolution from bottom (B) through middle $(M)$ to top $(T)$ sequences of basaltic rocks.

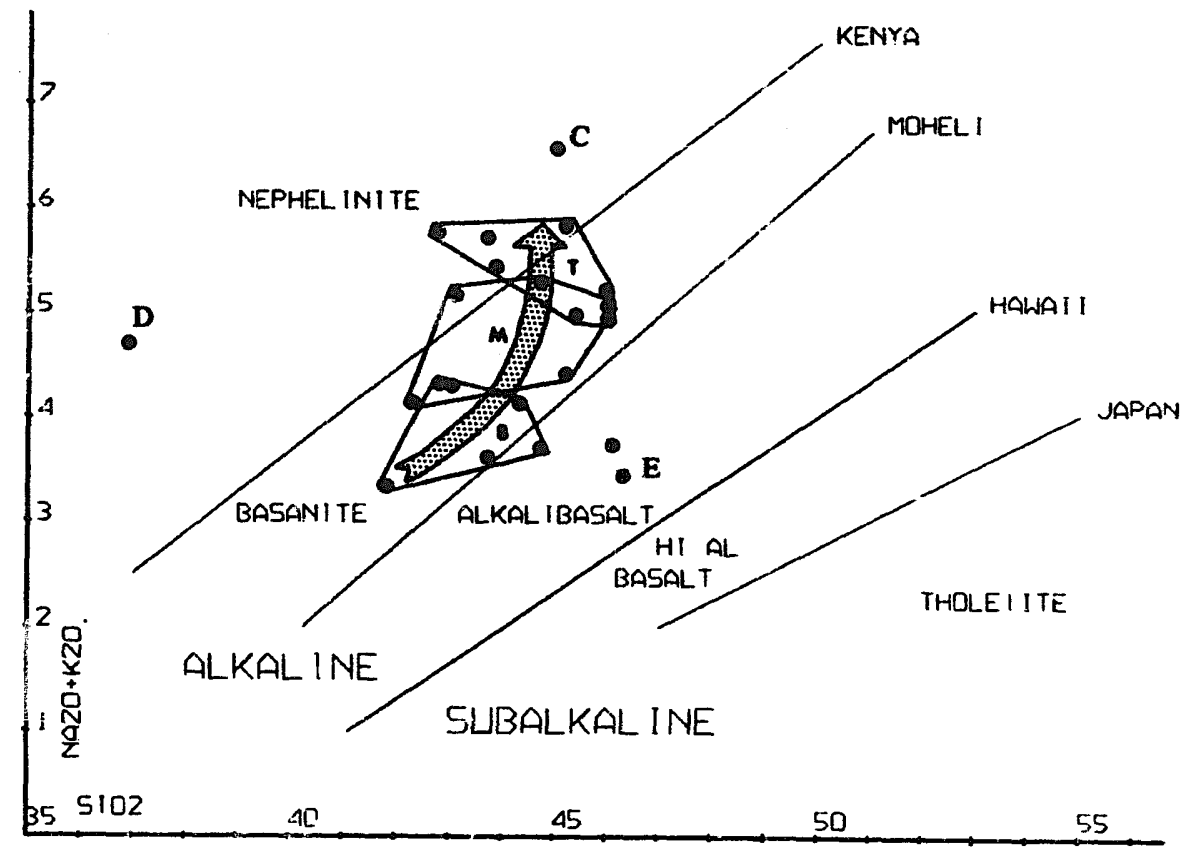

(E), and S55 (within the B field) are exceptions to a continuous chemical evolution from bottom to top, where an arrow shows the general trend of evolution, which is to be expected as a result of olivine and pyroxene fractionation for alkaline rocks at about $9 \mathrm{kbar}, 30 \mathrm{~km}$ depth (Green \& Ringwood 1967:156-157).

The alkali $\left(\mathrm{Na}_{2} \mathrm{O}+\mathrm{K}_{2} \mathrm{O}\right)$-iron $\left(\mathrm{FeO}+\mathrm{Fe}_{2} \mathrm{O}_{3}\right)-$ magnesia (MgO) or 'AFM' diagram has proven to be uscful to visualize magmatic differentiation. Differentiation trends for alkali basalt melts start as rich in magnesia, move towards a weak iron enrichment, and end enriched in alkalis. Seen from the AFM diagram (Fig. 8) the differentiation trend of the Skien basalts seems to follow the common route for alkali basalts. The diagram also shows that the direction of the

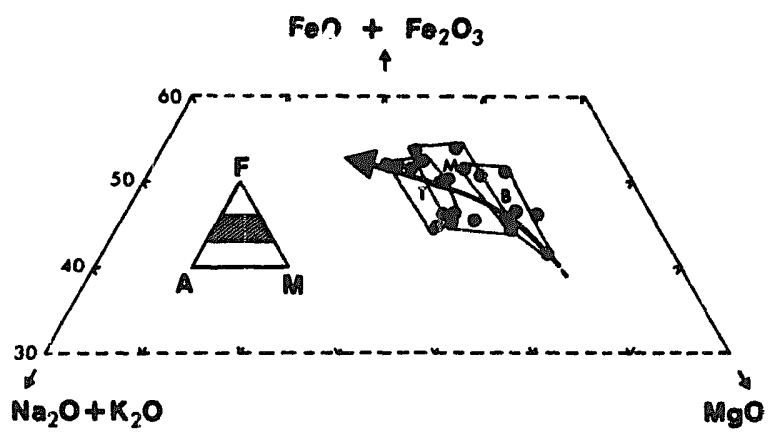

Fig. 8. Differentiation trend of the Skien basaltic rocks in an AFM diagram. differentiation trend follows the obseryed stratigraphy from bottom (B) through middle (M) to the top (T) sequence of the basalts.

The Skien basalt samples are also plotted in the phase diagrams (Fig. 9), both as originally analysed, and with all iron calculated as FeO. The points would be expected to lie along the cotectic lines, but do not reach them, due to the fact that the diagram is drawn from 1 atmosphere pressure experimental runs and the analysed samples are believed to contain phenocrysts formed before the complete crystallization took place at 1 atmosphere pressure. Only few high pressure experimental studies are known to have been done as yet in these systems (Onuma \& Yamamoto 1976). Therefore we don't know exactly where the cotectic lines will lie at elevated pressures. Since iron is expected to be an important component in a basalt melt, one must take into account that the diagram regresents only an iron-free system. There are also uncertainties concerning the norn calculations as discussed earlier. Al can also enter the diopside s1ructure as Tschermak's molecule, and piagioclase in basalts also contains some anorthite molecule. With the An-content of the plagioclase in $\mathrm{S} 63$ and $\mathrm{S} 69\left(\mathrm{An}_{20}-\mathrm{An}_{30}\right)$ in mind it is interesting to note that a bulk composition near the diopside-albite join crystallizes into a plagioclase with $A_{25}$ and aluminous diopside according to Yagi (1967). 


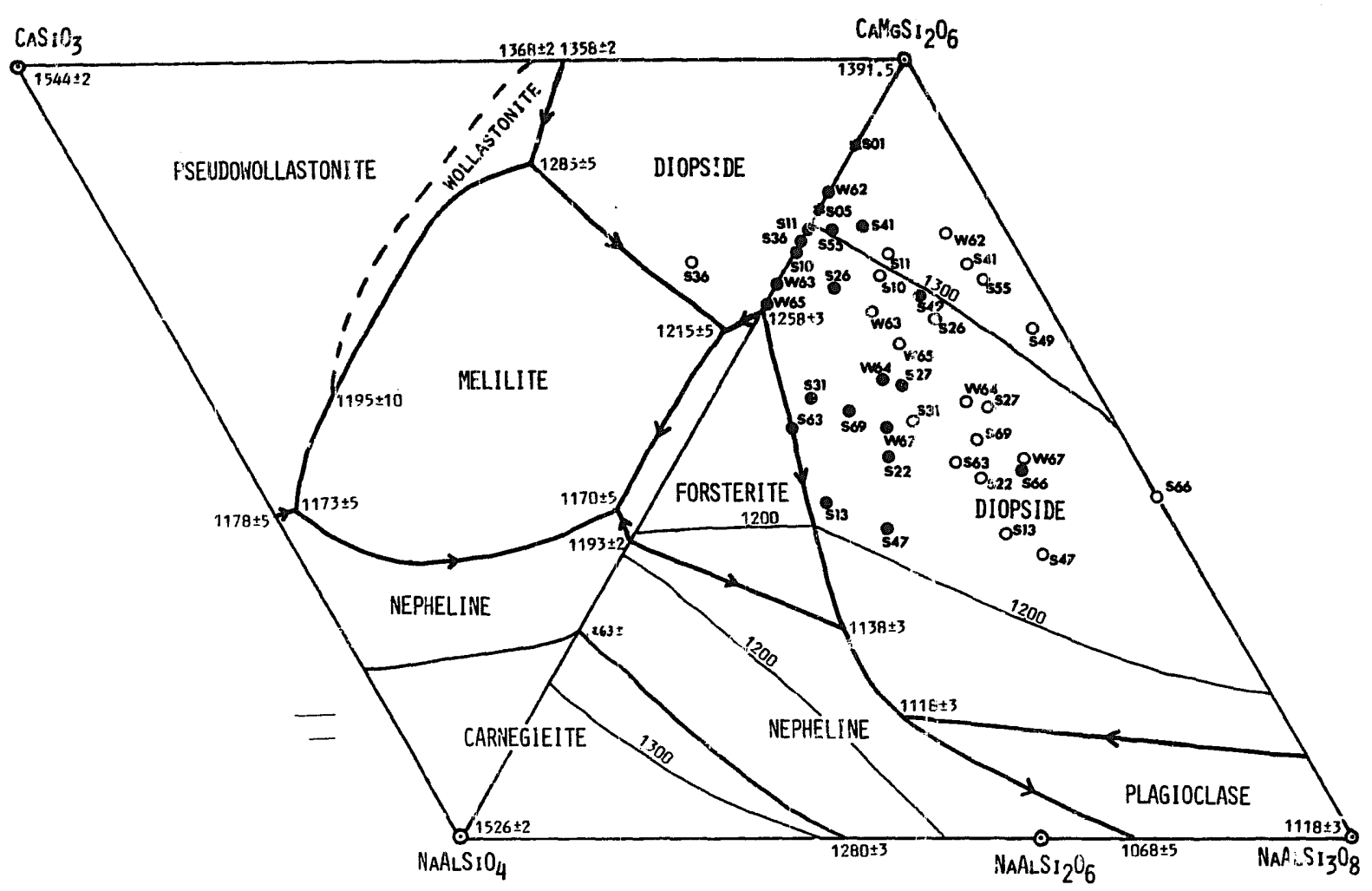

Fig. 9. Two 'coupled' diagrams: DI - NE - AB (right) as a redrawn part of the DI - NE - Q diagram by Schairer $\& t$ Yoder (1960), and PWO/WO - NE - DI (left) ty Schairer (1967), both fcund experimentally at 1 atmosphere pressure. Figures indicate tenperatures in ${ }^{\circ} \mathrm{C}$. Analyses of the Skien basaltic rocks are plotted as open circles; analyses where all iron is recalculated as $\mathrm{FeO}$ are plotted as filled circles. Asterisks are plotted when original and recalculated plots are locate.1 at the same point.

As a basis for a possible model for the genesis of the Skien basalts, the degree of differentiation, compiled from information in the $\mathrm{MgO}$ variation diagrams and the three different types of diagrams presented above, is qualitatively shown as a function of the crystallization order or 'stratigraphy' in Fig. 10. Both axes are therefore also time-dependent. The minerals present in the rocks, and the rock names, are also shown in the same diagram. Principally the main differentiation trend with stratigraphy is from ankaramites with pyroxene + olivine, towards basanite with plagioclase + pyroxene. There are, however, exceptions to the principal trend, where it seems that differentiation has occurred rather quickly.

From these facts the following model was constructed: A magma has differentiated by fractional crystallization, but smaller portions of magma have separated in subsidiary reservoirs, which also underwent fractional crystallization. The various extrusions of basalts have probably come at irregular intervals from different minor magma chambers and from the major magma mass, all of which were differentiating, but at different rates; the magma in the smaller magma chambers at a high rate, and the major magma mass at a lower rate. This seems to be consistent with the actual zoning of the pyroxeries.

\section{Numerical testing of crystal fractionation}

To test the hypothesis presented above a linear programming least squares computer mixing programme was used. This kind of fractionation calculation has been employed, for example, on the Columbia River basalt by Wright et al. (1973), and following their model the rock with highest $\mathrm{MgO}$ content has been taken as the parent rock in each calculation.

A total of 235 model runs have been executed on the computer. Some examples from the runs are shown in Table 7. The ideal mixing model is composed of a limited number of minerals to be fractionated. Another important factor is that the compositions of the minerals used in the calcula- 


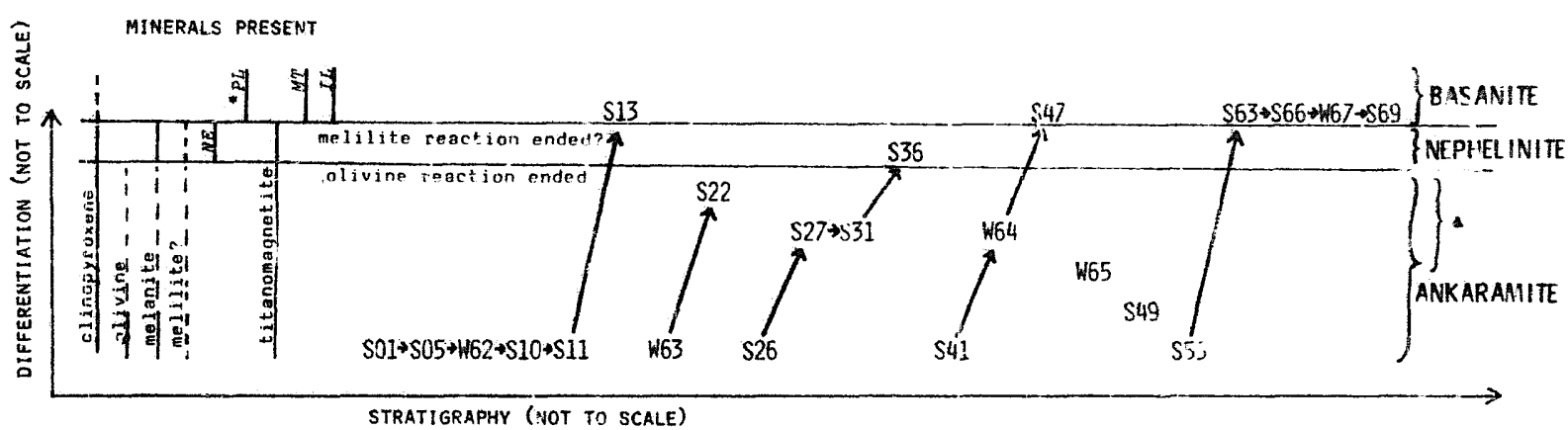

Fig. 10. Qualitative diagram showing increasing differentiation of samples from the Skien basaltic rocks against crystailization order ('stratigraphy' not to scale). Minerg!s principally present are shown to the left, phenocrysts indicated with asterisks: rock name to the right. $N E=$ nepheline, $P L=$ plagioclase, $M T=$ magnetite, $I L=$ ilmenite. $\Delta=$ Altered ankaramite with chlorite and calcite.

Table 7. Mineral values in \% of differentiatec srystals (crystals removed) to arrive at daughter from parent. testec by means of a computer.

\begin{tabular}{|c|c|c|c|c|c|c|c|c|}
\hline \multicolumn{2}{|l|}{ Rocks } & \multirow{2}{*}{$\begin{array}{l}\text { Run } \\
\text { No. }\end{array}$} & \multicolumn{5}{|l|}{ Minerils } & \multirow{2}{*}{ 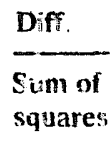 } \\
\hline Parent & Daughter & & Diopsite & Salite & Olivine & Magnetite & Ilmenite & \\
\hline S05C, Am & S11, Am & 41 & 2.4 & & 0.4 & & & 1.89 \\
\hline S10C, Am & $\$ 13, \mathrm{Bn}$ & 54 & & 34.0 & 0.3 & 4.7 & 0.9 & 4. 104 \\
\hline S11, Am & $\$ 13, \mathrm{Bn}$ & 141 & & 37.3 & 5.3 & 11.7 & 0.7 & 0.867 \\
\hline S41, Am & S49, Am & 30 & 20.0 & & 0.4 & 2.0 & 0.7 & 1.375 \\
\hline S41, Am & S55, Am & 28 & 15.1 & & 0.2 & & 1.4 & 1.887 \\
\hline S41, Am & S66, Bn & 134 & 39.7 & & & 3.5 & 1.4 & 4.42 \\
\hline
\end{tabular}

Am $=$ ankaramitc. $B_{n}=$ basanite

tion ought to be chosen within the compcsitional range of the observed phenocryst minerals. The only observed phenocrysts to be accounted for in the fractional crystallization of the Skien basalts are clinopyroxene (Ti-poor diopside and titaniferous salite), olivine, plagioclase, and kaersutite, while apatite, magnetite + ilmenite (as titanomagnetite) sometimes occur as microphenocrysts up to $0.5 \mathrm{~mm}$ size. Magnetite and ilmenite in minor amounts (as titanomagnetite) had to be present during fractionation to control the iron and titanium contents of the rocks.

To decide what was a good fit the sums of squares of all differences of all elements between observed and estimated daughtser rocks were examined. Comparing the observed and the estimated analyses, the analyses were taken to be practically equal (representing a good fit) when sum of squares of the differences was less than 2 . When the sum of squares of the differences was $2-5$, the fit was characterized as less good; while the fit was no accepted when sum of squares was greater then 5 .

Calculations among the different ankaramite lava flows seemed to be simple. The same was the case for calculations from ankaramite to basanite, though the fit was not always as good. Calculations from ankaramite to nephelinite, and among the basanites, however, seemed to be very difficult, and gave no satisfactory results. This is assumed to be a consequence of the many different phases present in the rocks. The number of phases increases with differentiation, and the number of reaction relationships among them also increase:

It must also be noted that the proportions of minerals involved in the calculations fit with observed mineral proportions in the rocks, and this can also be takent as a confirmation of the data obtained from the calculations.

From the computer runs the fractionation from ankaramite to basanite was calculated to 
generally involve $30-40 \%$ clinopyroxene fractionation. Crystal fractionation from one ankaramite to another would involve less clinopyroxene fractionation, generally $15-2,0 \%$ for lava flows with nearly equal compositions.

The mixing calculations confirm that all Skien basaltic rocks could principally be produced through clinopyroxene fractionation from the more primitive members of the series. Olivine, together with titanomagnetite, has played only a minor role in the crystal fractionation. Clinopyroxene fractionation seems to be a dominant feature of the early differentiation history of the Skien basalts, but clinopyroxene is later accompanied by more phases with possible reactions occurring among the phases, making problems for the computer fits.

\section{Comparisons with experimental work}

Studies in the system nepheline-diopside by Bowen $(1922,1928)$ showed that this system is not binary. Forsterite appears on the liquidus surface, and melilite appears as a solid phase at subliquidus temperatures. For instance, a mixture of $30 \% \mathrm{NE}$ and $70 \%$ DI begins to crystallize at $1270^{\circ} \mathrm{C}$ with separation of forsterite. This continues to separate until a temperature of $1240^{\circ}$ is reached, when diopside begins to separate and forsterite to dissolve. The resorption of forsterite continues until the temperature has failen to $1180^{\circ}$, and at about the same temperature melilite begins to separate. At temperatures below this the mass consists of diopside, melilite, and liquid.

The 'basalt tetrahedron' of Yocier \& Tilley (1962) is inadequate to ciescribe melilite-bearing lavas, which must be referred to an enlarged system forsterite-larnite-nepheline-silica, taking into account the Ca-rich composition of most molilites. This system is called the expanded basalt tetrahedron' and was introduced by Schairer \& Yoder (1964). A crystallization 'flowchart' was dedaced from their first studies, but this has been modified by later experiments. Modifications were found when anorthite was added to the system (Schairer et al. 1968) where it seemed that one important crystallization pât. tern led to a single eutectic at which nephelineplagioclase-diopside-melilite crystallize simultaneously. The crystallization sequences are such that diopside and nepheline are never seen to crystallize together without either meli- lite or plagioclase. This ey point may be reached by two different paths:

1. The nepheline basanites would be represented by a quaternary invariant point with NE, DI, AIN, FO. With loss of olivine the liquid moves to nepheline tephrite with NE, DI, AN, and further to melilite olivine nephelinite represented at a quaternary invariant point with NE, DI, MEL, FO. With further loss of olivine the liquid moves to olivine nephelinite with NE, DI, FO. A liquid crystallizing at this point will carry anorthite or melilite. The incompatibility of plagioclase and melilite in igneous rocks is pointed out by several authurs (e.g. Yoder \& Schairer 1969) and is supported by field observations on volcanic rocks in eastern Uganda (e.g. Nixon \& Clark 1967).

2. Schaiier \& Yoder (1964) and Schairer (1967) describe another possible path of crystallization from an olivine nephelinite with NE, DI, OL or an olivine melilitite with DI, OL, MEL. Through olivine fractionation these liquids will move towards oivine melilite nephelinite.

Olivine reaction with the liquid will give rise to melilite nephelinite. When olivine is completely consumed by the liquid, vvcllastonite will occur in a coinposition called wollastonite melilite nephelinite by Schairer \& Yoder (1964). At this point in the fractionation sequence the reaction of melilite with liquid takes place, precipitating a sodic plagioclase.

Schairer (1967:590) ard Yoder (1973:165) point out that there is as yet no petrographic evidence for this latter proc:ess. Schairer expects that wollastonite may combine with nepheline to form soda-melilite molecules in the melilites, or may be found as perovskite or sphene in Ti-rich rocks. Yoder $(1969,1973)$ states that melilite and anorthite react to form a clinopyroxene and garnet at low temperatures, and aluminous clinopyroxene and wollastonite at high pressures. The occurrence of melanite and aluminous clinopyroxene with melilite would be expected in the presence of iron and titanium.

There are, however, complications in fitting the simplified experimental models to the rocks. For instance olivine-free nephelinites without melilite cannot be fitted to the experimental models at all according to Bailey (1974). In the natural system $\mathrm{TiO}_{2}, \mathrm{~K}_{2} \mathrm{O}, \mathrm{Fe}, \mathrm{CO}_{2}$, and $\mathrm{H}_{2} \mathrm{O}$ are evidently important. To end up with an experimental model fitted to the Skien basalts is not an 
easy task, but it seems that the second crystailization path above describes a possible course of evolution for the magma. From the studies quoted above the olivine reaction clearly plays a very significant role in the early stage of these fractionation processes. Schairer et al. (1968) expect olivine resorption to be seen in natural nepheline-beariug suites, appearing as olivine mantled by fine aggregates of clinopyroxene. This is in fact observed very clearly in the lowermost Skien lava flows, as described above. The late crystallizing minerals are obviously melanite, nepheline, and ore in the lower $2 / 3$ of the Skien basalt pile; sphene also occurs occasionally and melilite may be present. The upper parts of the Skien basalts are characterized by a sodic plagioclase (An 20-30) without melilite. Clinopyroxene is the dominant mineral throughout the whole sequence of basalts, though it diminishes when plagioclase appears.

\section{Conclusions}

The experimental work by Schairer \& Yoder (1964) and Schairer (1967) quoted above apparently give melts of compositions sirnilar to that of the Skien basalts when starting with a melt of olivine nephelinite or olivine melilitite magma composition. From these experiments the whole series of Skien basalts are believed to represent differentiation from an initial magma with a composition possibly represented by olivine + nepheline, called olivine nephelinite. Clinopyroxene fractionation is thought to have played the most important role in the magmatic evolution of the Skien basalts, and the early olivinereaction and perhaps the late melilite-reaction have taken place to a lesser degree. The principal petrological evolution of the Skie a basalts may be summarized as a flow diagram (Fig. 11).

In conclusion, it seems likely that there has been an olivine nephelinite magma intrusion which at moderate depths has separated smaller portions of magma into minor reservoirs. The various extrusions of basalts have come at irregular intervals from the different minor magma chambers and from the major magma mass, all of which were differentiating at moderate pressures, but at different rates. The nature of the more undersaturated basaltic magmas (nepheiinites and melilitites) have been discussed by Green (e.g. 1969, 1970a, 1970b). From his works there is reason to believe that the Skien basalts

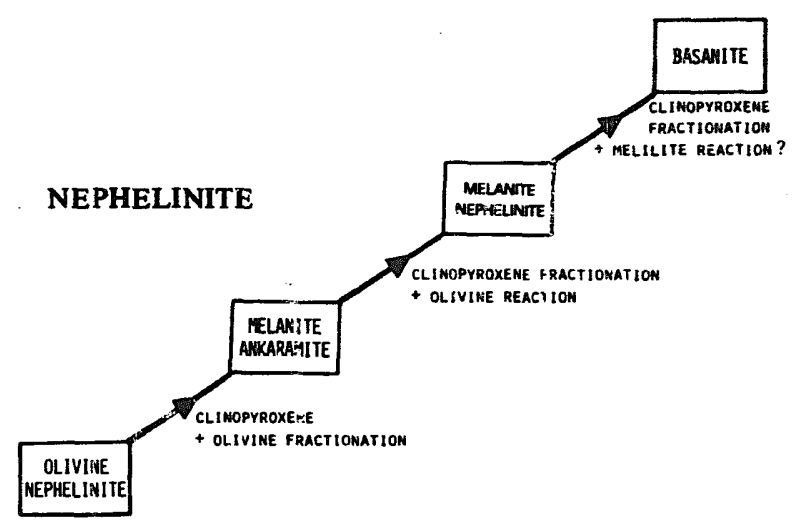

Fig. 11. Flow diagram for the magratic evolution of the Skien basaltic rocks from a possible olivine nephelinitic parent al magma.

have originated at great depths. The petrogenetic grid for mantle-derived basaltic magmas by Green (1970b) puts the origin of the olivinenephelinites to $\sim 30$ kbar pressure with $1-5 \%$ $\mathrm{H}_{2} \mathrm{O}$ in the melt; less than $10 \%$ rnelting of a pyrolite mantle may be involved. This depth ( $100 \mathrm{~km}$ ) corresponds to the low velocity zone. The low velocity zone of the upper mantle is interpreted by Green $(1970 \mathrm{~b}, 1971)$ as a region in which, due to the instability of amphibole in pyrolite containing $01-0.2 \% \mathrm{H}_{2} \mathrm{C}$ at depths in excess of $80-100 \mathrm{~km}$, there is a very small (less than 5\%) degree of partial melting. This liquid fraction is highly undersaturated olivine nephelinite or olivine melilitite. Ascent and extrusion of basaltic magmas may occur when the low velocity zone is tapped rather directly by major rift of fault systems, like the ones which might have initiated the formation of the contınental Oslo rifi.

Silica undersaturated lavas are most often accompanied by explosive extrusion of pyroclastic material, and contain ultramafic nodules implying a deep origin. The Skien nephelinite lava shows affinities with Fen damkjernite compositions, and the ankaramites show affinities with melteigite and ijolite compc sitions. The Fen alkaline complex is situated only $20 \mathrm{~km}$ away in the western direction. Here Griffin (1973) and Griffin \& Taylor (1975) reported lherzolite nodules in the kimlerlite-like damkjernite. A camptonite-dike is reported from Venst $\varnothing p$, Gjerpen, by Brøgger (1933b:33), and its composition is quite similar to that of the Skien basalts.

The Skier basalts are accompanied by rather few pyroclastic extrusions, and no ultramafic 
nodules have been found. Carmichael et al. (1974:599) also report that ultramafic nodules seem to be lacking, curiously enough, in the basanites of the whole East African province, the most extensive known region of nephelinite volcanism. Other nephelinitic-melilititic magmas come rather directly from the upper mantle to the surface (O'Hara 1965). Such magmas have differentiated mainly by olivine fractionation. It seems a possibility that their temporary residence and differentiation in magma chambers at intermediate pressure have caused the peculiar petrography of the Skien basalts. Clinopyroxene fractionation was thus the dominant process of evolution, followed by an olivine reaction, in contrast to the lower-pressure olivine fractionation more common in basalts. Any ultramafic nodules would sink during the shallow-level differentiation; if they remained the olivine-rich nodules vrould react with the melt. This may explain the absence of uttramafic nodules in these rocks.

Acknowledgements. - Thanks are due to Curator J. A. Dons, who suggested the stud! and introduced me to the field, and to Curator W. L. Griffin for all help with the microprobe and for several helpful discussions. The field work was financed by Mineralogisk-Geologisk Museum, Oslo. The mantuscript benefited from critical review by Director G. E. Sigvaldason. Special thanks are also due to Professor J. A. W. Bugge and Director H. S. Yoder, J i. for their encouragement.

\section{References}

Albee, A. L. \& Ray, L. 1970: Correction factors for electron probe microanalysis of silicates, oxides, carbonates, phosphates, and sulfates. Anal. Chem. 42, 1408-1414.

Bailey, D. K. 1974: Nephelinites and ijolites, pp. 53-66 in Sørensen, H. (ed.), The Alkaline Rocks, John Wiley \& Sons, Inc.

Barth, T. F. W. 1945: Studies on the igneous rock complex of the Oslo Region. II. Systematic pearography of the plutonic rocks. Skr. Norske Vidensk.-Akad. i Oslo. I. Mat.-Naturv. KI., No. 9, 104 pp.

Bence, A. E. \& Albee, A. L. 1968: Empirical correction factors for the electron microanalysis of silicates and oxides. J. Geol. 76 382-403.

Bowen, N. L. 1922: Genetic features of alnoitic rocks from Isle Cadieux, Quebec. Am. J. Sci. 3, 1-14.

Bowen, N. L. 19.8: The Evolution of the lgneous Rocks, Dover Publications, Inc., New Y srk.

Brooks, C. K. \& Rucklidge, J. C. 1973: A Tertiary lamprophyre dike with high pressure xenoliths and megacrysts from Wiedemanns fjord, east Greenland. Contrib. Mineral Petrol. 42, 197-212.

Brøgger, W. C. 1884: Spaltenverwerfungen in der Gegend Langesund - Skien. Nys. Mag. 28, 253-419.

Brøgger, W. C. 1911: Reference in Oftedahl (1952).

Brogger, W. C. 1933a: Essexitrekkens erupsjoner. Nor. Geol. Unders. 138. $103 \mathrm{pp}$.
Brøgger, W. C. 1933b: Die Eruptivegesteine des Oslogebietes. VII. Die chemiscine Zusammensetzung der Eruptivgesteine des Cislogebietes. Skr. Nor. Vidensk.-Akad. i Oslo, Mat.Naturvidensk. Kl., No. I. 147 pp.

Carmichael, I. S. E., Turner, F. J. \& Verhoogen, J. 1974: Igneous Petrology, McGraw-Hill.

Clark, S. P., Schairer, J. F. \& de Neufville, J. 1962: Phase relations in the system $\mathrm{CaMgSi}_{2} \mathrm{O}_{6}-\mathrm{CaAl}_{2} \mathrm{SiO}_{6}$ at low and high pressure. Carnegie Inst. Wash. Yearb. 61, 59-68.

Dahll, T. 1857: Profile durch die Gegend von Skien, Porsgrund und Langesund. In Kjerulf, T., Ueber die Geologie des südlichen Norwegens. Nyt. Mag. 9, 306-333.

Deer, W. A., Howie, R. A. \& Zussman, J. 1966: An Introduction to the Rock-Forming Minerals, Longmans.

Dons, J. A. \& Györy, E. 1967: Permian sediments, lavas, and faults in the Kolsås area W of Oslo. Nor. Geol. Tidsskr. 47, 57-77.

Eskola, P. 1920-21: The mineral facies of rocks. Nor. Geol. Tidsskr. 6, 143-194.

Goldschmidt, V. M. 1911: Die Kontaktmetamorphose im Kristiania-Gebiet. Vid.-Selsk. Skr., I. Mat.-Naturvidensk. KI., No. I. $483 \mathrm{pp}$.

Green, D. H. 1969: The origin of basaltic and nephelinitic magmas in the Earth's mantle. Tectonophysics 7, 409-422.

Green, D. H. 1970a: A review of experimental evidence on the origin of basaltic and nephelinitic magmas. Phys. Earth Planet. Int. 3, 221-235.

Green, D. H. 1970b: The origin of basaltic and nephelinitic magmas. Trans. Leichester Lit. Phil. Soc. 64, 28-54.

Green, D. H. 1971: Compositions of basaltic magma as indicators of conditions of origin: application to oceanic volcanism. Phil. Trans. Roy. Soc. Lond., Ser. A 268, 707-725.

Green, D. H. \& Ringwood, A. E. 1967: The genesis of basaltic magmas. Contrib. Mineral. Petrol. 15, 103-190.

Giriffin, W. L. 1973: Lherzolite nodules from the Fen alkaline complex, Norway. Contrib. Mineral. Petrol. 38, 135-146.

Griffin, W. L. \& Taylor, P. N. 1975: The Fen damkjernite: petrology of a "central-complex kimberlite". Phys. Chem. Earth 9, 163-177.

Huckenholz, H. G. 1965: Der petrogenetische Werdegang der Klinopyroxene in der tertiären Vulkaniten der Hocheifel, I. Die Klinopyroxene der Alkaliolivinbasalt - Trachyt - Assoziationen. Contrib. Mineral. Petrol. 11, 138-195.

Hqleg, O A. 1936: The lower Permian flora of the Oslo Region. Nor: Geol. Tidsskr. 16, 1-43.

Keilhau, B. M. 1826: Darstellung der Uebergangsformation in Norwegen, Leipzig.

Kesson, S. \& Price, R. C. 1972: The major and trace elemen: chemistry of kaersutite and its bearing on the petrogenesis of alkaline rocks. Contrib. Mineral. Petrol. 35, 119-124.

King, B. C. 1965: Petrogenesis of the alkaline igneous rock suites of the volcanic and intrusive centres of Eastern Uganda. J. Petrol. 6, 67-100.

Kiar, J. 1906: Das Clbersilur im Kristianiagebiete. Vid.-Selsk. Skr., Mar.-Naturvidensk. Kl., No. 2. 596 pp.

Kjerulf, T. 1855: Das Christiania Silurbecken, chemischreognostisch untersucht. Christiania (Oslo).

Kuno, H. 1960: High-alumina basalt. J. Petrol. I, 121-145.

Macdonald, G. A. \& Katsura, T. 1954: Chemical composition of Hawaiian layar. J. Petrol. 5, 82-133.

Mörtel, H. 19i1: Foide und Zeolithe (Restkristallisate) basaltischer Gesteine des Vogelberges (Hessen). Neues Jahrb. Miner. Abh. 115, 54-97.

Neumann, E.-R, 1976: Two new refinements for the calculation of structural formulae for pyroxenes and amphiboles. Nor. Geol. Tidsskr. 56, 1-6. 
Nixon, P. H. \& Clark, L. 1967: The alkaline centre of Yelele and its bearing on the petrog nesis of other eastern $U_{\text {ganda }}$ volcanoes. Geol. Mag. 104, 4 55-4/2.

Oftedahl, C. 1952: Studies on tis igneous rock complex of the Oslo Region. XII. The lavas. Skr. Norske Vidensk.-Akad. i Oslo. I. Mat.-Naturv. Kl., No. 3.

Oftedahl, C. 1957: Permian izneous rocks, pp. 26-32 in Holtedahl, O. \& Dons, J. A. (eds.): Geological guide to Oslo and district. Skr. Norske Vidensk.-Akad. i Oslo. I. MatNaturv. Kl., No. 3.

O'Hara, M. J. 1965: Primary magmas and the origin of basalts. Sicottish J. Geol. I, 19-40.

Onuma, K. \& Yamamoto, M. 1976: Crystallization in the silica-undersaturated portion of the system diopsidenepheline-akermanite-silica and its bearing on the formation of melilitites and nephelinites. J. Fac. Sci., Ho'kkaido Univ., Ser. IV, I7, 347-355.

Poldervaart, A. \& Hess, H. H. 1951: Pyroxenes in the crystallization of basaltic magma. J. Geol. 59, 472-489.

Ramberg, I. B. 1976: Gravity interpretation of the Oslo Graben and associated igneous rocks. Nor. Geol. Unders. 325. 194 pp.

Saggerson, E. P. \& Williams, L. A. J. 1964: Ngurumanite fron southern Kenya and its bearing on the origin of rocks in the northern Tanganyika alkaline district. J. Petrol. 5, 40-81.

Schairer, J. F. 1967: Phase-equilibria at one atmosphere related to tholeiitic and alkali basalts, pp. 568-592 in Abelson, P. H. (ed.): Researches in Geochemistry, Vol. 2, Wiley di. Sons, Inc.

Schairer, J. F. \& Yoder, H. S. Jr. 1960: The nature of residual liquids from crystallization, with data on the systern nepheline-diopside-silica. Am. J. Sci. 258-A, 273-283.

Schairer, J. F. \& Yoder, H. S. Jr. 1964: Crystal and liquid trends in simplified alkali basalts. Carnegie Inst. Wash. Yearb. 63, 65-74.

Schairer, J. F., Tilley, C. E. \& Brown, M. A. 1968: The join nepheline-diopside-anorthite and its relation to alkali basa't fractionation. Carnegie Inst. Wash. Yearb. 66, 467-471.

Segalstad, T. V. 1975: Cauldron subsidences, ring-structures, and major faults in the Skien district, Norway. Nor. Geol. Tidsskr. 55, 321-333.

Shand, S. J. 1939: On the staining of feldspathoids, and on zonal structure in nepheline. Am. Mineral. 24, 508-513.

Streckeisen, A. 1967: Classificationi and nomenclature of igneous rocks. Neues Jahrb. Miner. Abh. 107, 144-240.

Strong, D. F. 1972: Petrology of the island of Moheli, Western Indian Ocean. Gev:. Soc. Am. Bull. 83, 389-406.

Størmer, L. 1966: Jordens og livets historie, Iniversitetsforlaget. 275 pp.

Weigand, P. W. 1975: Studies on the igneous rock compiex of the Oslo Region. XXIV. Geochemistry of the Oslo basaltic rocks. Skr. Norske Vidensk.-Akad. i Oslo, Mat.Naturvidensk. Kl., Ny Ser. No. 34.38 pp.

Wilkinson, J. F. G. 1974: The mineralogy anci petrography of alkali basaltic rocks, pp. 67-95 in Sørensen. H. (ed.): The Alkaline Rockss, John Wiley \& Suns, Inc.

Winkler, H. G. F. 1967: Petrogenesis of Metamorphic Rocks, 2nd ed.. Springer-Verlag.

Wright, T. L., Grolier, M. J. \& Swanson, D. A. 1973: Chemical variation related to the stratigraphy of the Columbia River basalt. Geol. Soc. Am. Bull. 841. 371-386.

Yagi, K. 1967: Silicate systems related to basaltic rocks, pp. 359-400 in Hess, H. H. \& Poldervaart, A. (eds.): Basalts. $l$. Intersci ence, John Wiley \& Sons, Inc.

Yagi, K. \& Onuma, K. 1967: The join $\mathrm{CaMgSi}_{2} \mathrm{O}_{6}-\mathrm{Ca}-$ $\mathrm{TiAl}_{2} \mathrm{O}$ and its bearing on the titanaugites. J. Fac. Sci.. Hokkaito Univ., Ser. IV. 13, 463-483.

Yagi, K., Hariya, Y., Onuma, K. \& Fukushima, N. 1975: Stability relation of kaersutite. J. Fac. Sci., Hokkaido Univ., Ser. IV, 16, 331-342.

Yoder, H. S. Jr. 1969: Anorthite-akermanite and albite-soda melilite reaction relations. Carnegie Inst. Wash. Yearb. 67. 105-108.

Yoder, H. S. Jr. 1973: Melilite stability and paragenesis. Fortschr. Miner. 50, 140-173.

Yoder, H. S. Jr. \& Tilley, C. E. 1962: Origin of basalt magmas: An experimental study of natural and synthetic rock systems. J. Petrol. 3, 342-532.

Yoder, H. S. Jr. \& Schairer, J. F. 1969: The meliliteplagioclase incompatibility dilemma in igneous rocks. Carnegie Inst. Wash. Yearb. 67, 101--105.

Accepted for publication November 1978 Printed July 1979 